\title{
A REVISION OF THE PROTEROZOIC-ARCHEAN BOUNDARY OF THE NORTHERN BOTHNIAN SCHIST BELT WITH A DISCUSSION OF THE GEOCHEMISTRY OF RELATED BASIC METAVOLCANICS
}

\author{
YRJÖ KÄHKÖNEN; ESA MATTILA and JUHANI NUUTILAINEN
}

KÄHKÖNEN, Y.; MATTILA, E., and NUUTILAINEN, J. 1986: A revision of the Proterozoic-Archean boundary of the Northern Bothnian schist belt with a discussion of the geochemistry of related basic metavolcanics. Bull. Geol. Soc. Finland 58, Part 1, 109-129.

Geophysical analysis suggests the need for a revision of the eastern border of the early Proterozoic Northern Bothnian (or Kiiminki) schist belt. Recent geological field work has revealed places where the discordance and hiatus between Proterozoic and Archean formations are seen or have been constructed.

The geochemistry of the basic rocks (mainly metavolcanics) on both sides of the discordance is compared on the basis of XRF-analyses for major and some trace ( $\mathrm{Zr}, \mathrm{Cr}, \mathrm{Ni}, \mathrm{V}, \mathrm{Cu}, \mathrm{Zn}$ and $\mathrm{Sr}$ ) elements from 80 samples and neutron activation analysis for rare earth elements (REE) from 26 samples. The rocks are divided into groups (the Archean volcanigenic amphibolites of Puutturi and Käkiperä, the Archean metagabbros of Kalliomaa, the Proterozoic metadiabases of Puutturi and Käkiperä, and the Proterozoic metabasalts of the Kiiminki schist belt), all of which have individual geochemical characteristics.

The basic rocks tend to have tholeiitic affinities (as revealed by $\mathrm{Ti} / \mathrm{Zr}$ and $\mathrm{V} / \mathrm{Zr}$ diagrams) but the Archean amphibolites of Puutturi are calc-alkaline. The latter group and the metagabbros of Kalliomaa are higher in $\mathrm{Cr}$ than are the other groups (at low $\mathrm{Zr}$ ) and the Proterozoic metadiabases are lower in $\mathrm{Cr}$ than are the metabasalts of the schist belt (at low $\mathrm{Zr}$ ). Chondrite-normalized REE patterns vary from consistent LREE enrichments in the Puutturi amphibolites to LREE depletions in the MORB-like pillowed metabasalts of the schist belt. The metadiabases are enriched in LREE but have convex-up patterns. The amphibolites of Käkiperä and the metagabbros of Kalliomaa display both depletions and enrichments in LREE.

Fractional crystallization has caused some of the variation within the groups but cannot be the cause of all the features observed. It is also evident that the Proterozoic metadiabases and the metabasalts of the schist belt are not comagmatic.

Key words: Proterozoic, Archean, metasediments, metabasalts, geochemistry, trace elements, rare earth elements.

Y. Kähkönen: Department of Geology, University of Helsinki, P.O. Box 115, SF-00171 Helsinki, Finland.

E. Mattila: Rautaruukki Oy, Raahe Steel Works, SF-92170 Raahensalo, Finland.

J. Nuutilainen: Lapin Malmi, Outokumpu Oy, Exploration, Kairatie 56, SF-96100 Rovaniemi, Finland. 


\section{Introduction}

The Northern Bothnian (Pohjois-Pohjanmaa) Proterozoic schist belt is situated in northern Finland at the margin of Archean (to the NE) and Proterozoic (to the SW) terrains. The Finnish name was given by Enkovaara et al. (1953) in their explanation to the $1: 400000$ geological map sheets of Oulu and Tornio. The belt is also known as the Kiiminki schist belt and this name is used here, too. Honkamo (1980) regards the belt as a Kalevian complex. The most common formations are conglomerates and greywackes of sedimentary origin. Among the greywackes there are also basic volcanics and some chemical sediments. In many places the Kalevian sedimentation began directly onto Archean basement. Thus, Jatulian formations are either absent or rare.

The extent of the schist belt is shown in Fig. 1 after Simonen (1980a and b), who drew the boundaries according to Geological Survey map sheets. The extent of the belt has not yet been fully determined on a stratigraphical basis.

Rautaruukki Oy carried out ore exploration in the Northern Bothnian schist belt between 1979 and 1984. The field operations were concentrated on the middle and eastern parts of the belt in an area dominated by basic volcanics and chemical sediments. In connection with these studies aerial and ground geophysical (magnetic, electromagnetic and gravity) data were analysed. It was revealed that, in some areas of Kalevian rocks, older formations may exist in windows or embayments and thus the area in question might consist of dissimilar complexes.

These problems are discussed in this paper by presenting some geophysical and geological observations on the eastern and southeastern part of the schist belt as a contribution to later mapping and stratigraphic studies. Much of the evidence is given in the form of geochemical comparison of basic rocks. Similar survey is called for on the other side of the belt as well.

\section{Evaluation from geophysical data}

The Northern Bothnian schist belt has been mapped by modern aerogeophysical methods, which can be used for evaluating the geological structures and extent of the belt. The most prominent directions of the anomaly axes in the schist belt are c. NW-SE, corresponding to the Karelian strike. Magnetic anomaly axes to the east and north of the schist belt strike more or less $\mathrm{N}-\mathrm{S}$ as is common for upper Archean schist belts in Finland. By examining the direction of the anomalies and the nature of their magnetic and gravity fields, T. Shulga (Sevzapgeologija, Leningrad) compiled an unpublished interpretation map of the geophysical fields as part of an iron ore prognosis project for Rautaruukki Oy in 1980-1984. Generalizing of this map permits a simple interpretation to be made (Fig. 2). The hatched areas represent combinations of geophysical fields typical of the schist belt and the stippled areas those typical of upper Archean formations (e.g. Kuhmo schist belt). It is geophysically feasible that the Northern Bothnian schist belt can be limited to cover the hatched area only. The extent would then be somewhat smaller than that indicated in Fig. 1. For instance, the long staurolite-mica schist unit forming a distinct magnetic anomaly at the eastern edge of schist belt could be Archean in age and have continuations northwards in the Pudasjärvi basement area. The boundaries cannot, however, be determined exactly by this interpretation alone, because of the lack of accuracy of generalizations and the thin, subhorizontal Proterozoic formations known to exist in the eastern part of the belt. We conclude that geophysical analysis gives only an approximately correct impression of the main tectonic units; it remains for geological mapping to provide a more precise picture.

\section{The general geological setting}

The bedrock in the area investigated consists of the Archean Pudasjärvi Granite Gneiss 


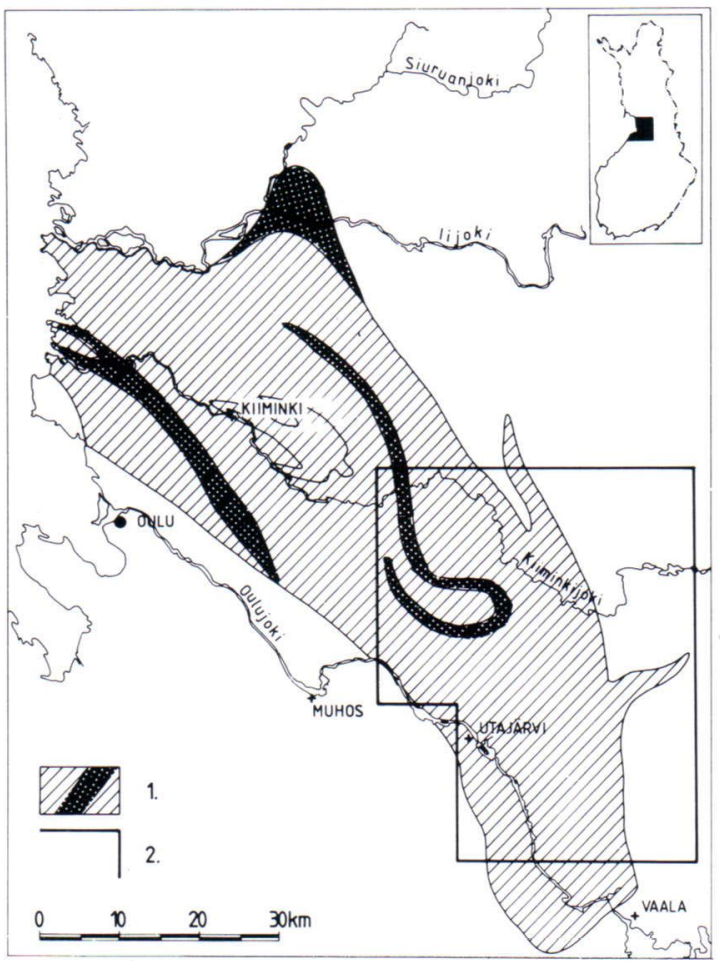

Fig. 1. 1 = The Northern Bothnian schist belt according to Simonen (1980a and b). Volcanic rocks are shown as dark. $2=$ The location of Fig. 3 .

Complex overlain by the Proterozoic Northern Bothnian schists, also known as the Kiiminki schist belt.

The geology of this region has been described by Mäkinen (1916), Wilkman (1931), Enkovaara et al. (1953) and Honkamo (1980, 1985). Rautaruukki Oy has carried out systematic geological mapping on sheets 342402,05 and 08 and in the Puutturi, Kattilasalmi and Kalliomaa areas, and field reports on these areas were drawn up for internal use by Arhe (1983 a and b). The geological information on the remaining area in Fig. 3 was compiled during various exploration programmes and is thus rather unsystematic. The field observations by Honkamo were also used in the outlining of the geological features of the southern part of the area. Open swamps and moraine formations cover large areas and make it difficult to study the bedrock. As much geo-

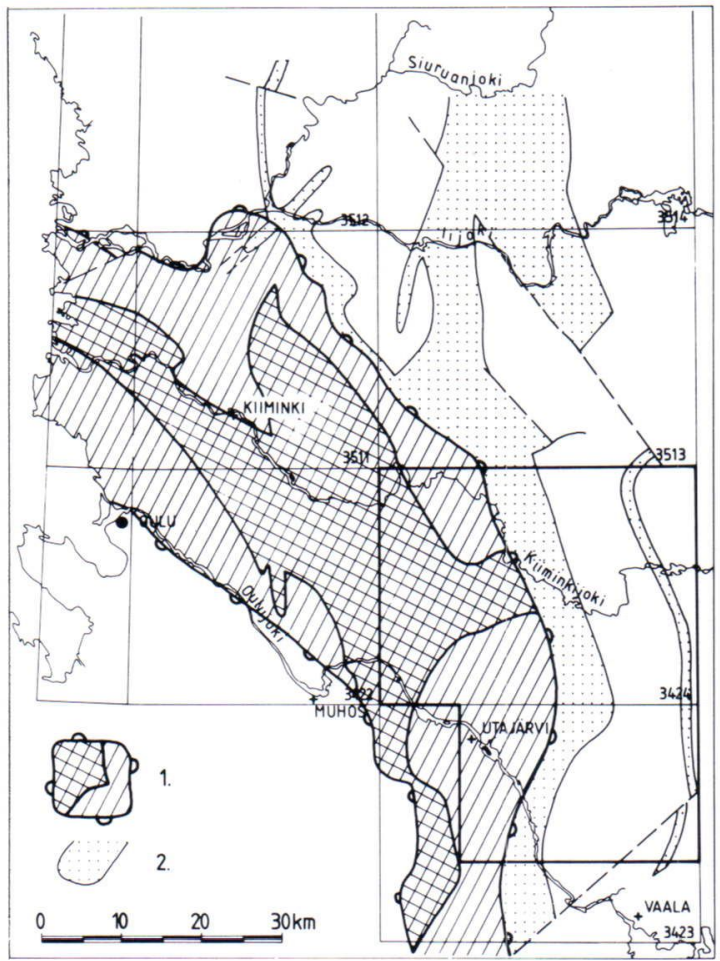

Fig. 2. See text for explanation. The area of Fig. 3 is shown.

physical information as possible has been utilized in the construction of the geological map of the area.

The basement complex underlying the Proterozoic schists can be divided into at least three different types: 1. Migmatitic gneiss in which the nebulitic paleosome is composed of mediumgrained banded mica gneiss or quartz-feldspar gneiss, and the neosome of heterogeneous granitic or trondhjemitic material. 2. Rather homogeneous medium-grained, generally foliated orthogneissic granodiorite. 3. Heterogeneous granitic gneiss. No attempt has been made on the geological map to distinguish between different types of gneiss. Amphibolitic metavolcanics associated with more acidic members are encountered as isolated patches in the granite gneiss area; they do not form continuous greenstone belts.

Metadiabase dykes, varying in size and direc- 


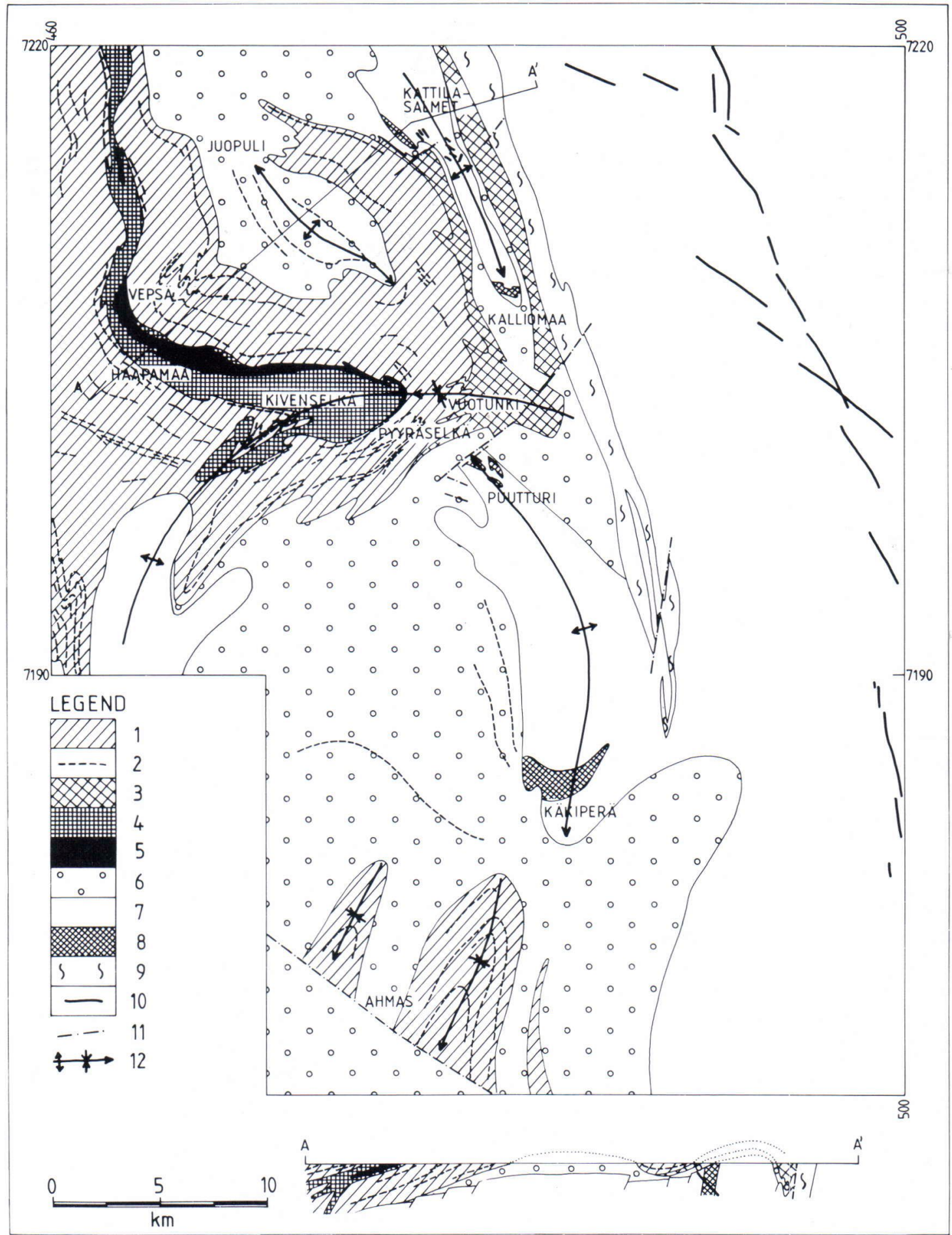

Fig. 3. Geological map of the area investigated. Proterozoic rocks: $1=$ Greywacke. $2=$ Black schist. $3=$ Mica schist. 4 = Basic volcanics. $5=$ Chemical sediments. $6=$ Arkose and conglomerate. Archean rocks: $7=$ Granite gneiss. $8=$ Amphibolite and metagabbro. 9 = Magnetite-bearing staurolite-mica gneiss. Other symbols: $10=$ Metadiabase. $11=$ Fault. 12 = Antiform, synform, axial plunge. 


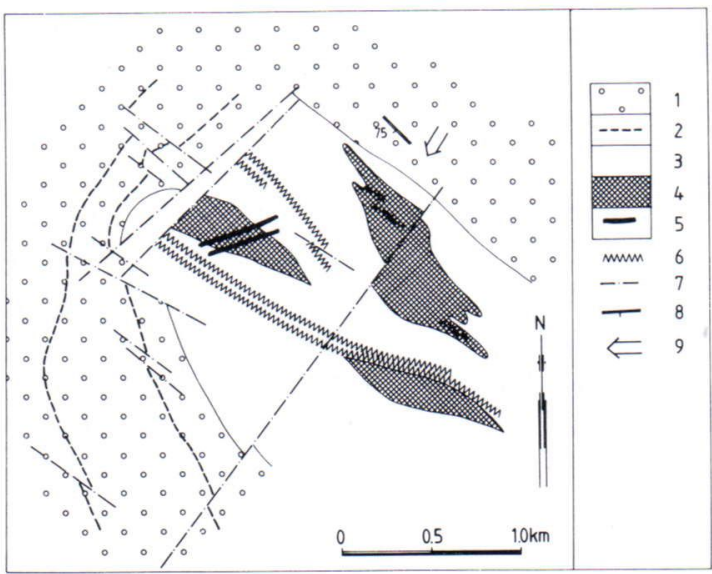

Fig. 4. Geological map of Puutturi. 1 = Arkose and conglomerate. 2 = Black schist. 3 = Granite gneiss. $4=$ Amphibolite. $5=$ Metadiabase. 6 = Breccia zone. 7 = Fault. 8 = Bedding plane. 9 = Bottom direction of sedimentation.

tion, are fairly common in the granite gneiss area, but have never been met with in the Proterozoic area.

The Proterozoic sedimentation on the granite gneiss usually started with arkose and conglomerate. In Puutturi these rocks may be underlain by remnants of weathering crust and possibly by Sariolan conglomerate. In the Kattilasalmi area, there is a layer of arkose just a few metres thick between the granite gneiss and andalusite-, cordierite-, and staurolite-bearing mica schists, but here the contact may be tectonic.

The very gentle dip of the bedding planes is characteristic of the Proterozoic area investigated, and in many places the sediments appear to be overlying the basement in their original position. In the eastern part, the folding was more intense, and the faulting also affected the structure of the area. Because of the gentle crossfolds, stratigraphically lower units and the basement are often exposed in the culminations. The upper units in the stratigraphic succession are exhibited in synclines and depressions, e.g. in the Ahmas area.

The arkoses and conglomerates repi esent formations deposited in the base-of-slope setting of the sedimentary basin (see also Honkamo 1985).

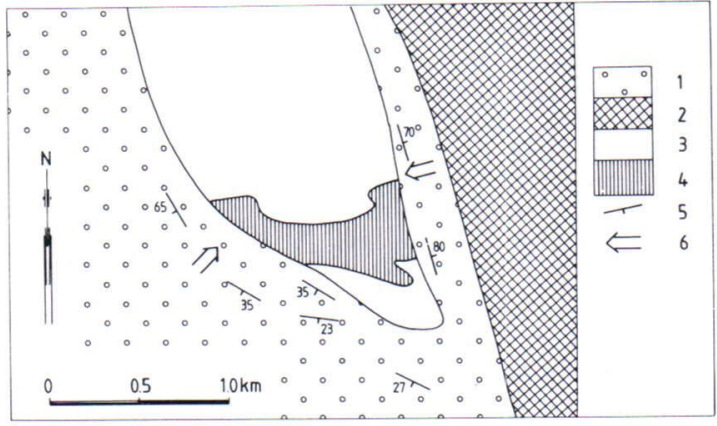

Fig. 5. Geological map of Kalliomaa. $1=$ Arkose and conglomerate. 2 = Mica schist. 3 = Granite gneiss. 4 = Metagabbro. 5 = Bedding plane. $6=$ Bottom direction of sedimentation.

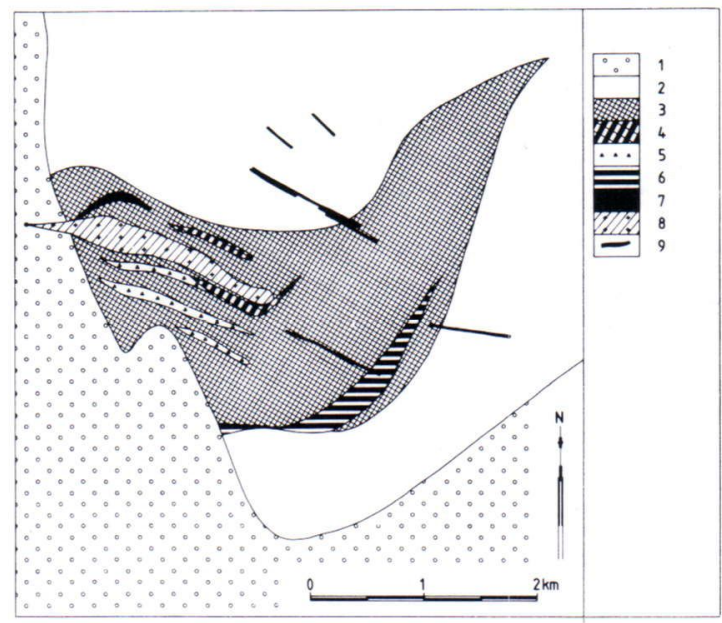

Fig. 6. Geological map of Käkiperä. 1 = Arkose and conglomerate. 2 = Granite gneiss. $3=$ Amphibolite. $4=$ Mica schist. 5 = Skarn. 6 = Quartz-feldspar schist. 7 = Sulphide ore. $8=$ Pegmatite. $9=$ Metadiabase.

The sediments of the shelf facies have probably been eroded.

In the Puutturi area (Fig. 4) most of the Proterozoic material is arkose; conglomeratic material is met with only as thin intercalations. Fine-grained mica schist and black schist intercalations are also rather common. The clasts of conglomerate are composed mainly of quartz and various types of granite gneiss. Angular schist fragments also met with are probably autobreccia fragments formed during sedimentation. Graded bedding is a common feature in the Puutturi 
arkoses. The amphibolites in Puutturi are characterized by heterogeneities of texture and composition. The rock is often volcaniclastic agglomerate, tuff and tuffite, but some are possibly of lava origin. The proportion of originally pumiceous material is quite high in places. The metadiabases in Puutturi are homogeneous, nonoriented rocks, often with gabbroic affinities.

The Proterozoic rock in the Kalliomaa area (Fig. 5) and its vicinity is mainly conglomerate. Its matrix is mica-bearing arkose and clasts are quartz and granitoidic gneisses. Staurolite-micagneiss and garnet-mica-gneiss pebbles are also met with in the conglomerate. Just a few pebbles occur in many parts of the conglomerate and, in general, the sorting is poor or absent. Crossbedding and carbonate bearing intercalations are occasionally encountered. The metagabbro in Kalliomaa is a medium-grained plagioclaseamphibole rock, often with rather well preserved blastophitic and blastopoikilitic textures. Amphiboles are often relics after pyroxene.

In the Käkiperä area (Fig. 6) there are only a few outcrops in the Proterozoic arkose and conglomerate. The Archean amphibolites are heterogeneous with tuffs and rocks of lava origin (e.g. flow-breccias). Skarn, mica schist and quartzfeldspar-schist occur as intercalations in the metavolcanic formation. The metadiabases are much like those in the Puutturi area and do not display the signs of polyphase deformation so evident in the amphibolites.

The contact between the arkose-conglomerate formation and the greywacke formation in the Kiiminki schist belt has been outlined on the basis of features visible on aeromagnetic maps. The greywacke has been intersected by drilling, e.g. in the Vepsä area where it contains abundant Alrich porphyroblasts (cordierite, andalusite and staurolite), and the primary structures are partly destroyed. Farther east, clastic arenite beds and mica schist beds alternate and the rock type is more easily recognizable as greywacke.

Black schist intercalations distinguishable as electric conductors because of their graphite con- tent are very common in the greywacke formation.

If the beds in the Vepsä area are, as it now seems, in their original stratigraphic sequence, the greywackes are overlain by the products of volcanic activity. Lowest of all there is usually a bed of tuffs and lavas. After they had deposited, volcanic activity calmed down for a while, and exhalative chemical sediments (including chert, iron formation and dolomite) precipitated during the intereruptive period. Clastic sedimentation producing mica schists also occurred. Its material was partly pelitic weathering products, partly tuffs. The thickness of the volcanic sedimentary formation is $200-500 \mathrm{~m}$.

During the main period of volcanism lava flows erupted. The lavas often show amygdaloidal pillow structures and volcanic breccias, but massive lava types are also common. Pyroclastic rocks are rare in the main volcanic formation. The eruption of the lava flows was probably associated with the fissures opened during the basin-building tectonic movements. Clastic sedimentation continued after the volcanic period with deposition of the upper greywackes.

The samples from Vepsä represent the lower volcanic unit whereas those from Pyyräselkä, Kivenselkä and Haapamaa represent the main period.

\section{Geochemical characteristics of the basic rocks}

The geochemical features typical of the basic rocks studied are given in Figures 7-11 (see also Table 1). Differences between tholeiitic and calcalkaline affinities are not always obvious on AFM diagrams. In these cases in particular $\mathrm{Ti} / \mathrm{Zr}$ and $\mathrm{V} / \mathrm{Zr}$ diagrams are useful for distinguishing between tholeiitic trends (marked increase in $\mathrm{Ti}$ and $\mathrm{V}$ between $50-150 \mathrm{ppm} \mathrm{Zr}$ ) and calcalkaline trends.

The metavolcanics of the Kiiminki schist belt are characteristically basalts with tholeitic affinities (Fig. 7 a). They are mostly low-K rocks, 


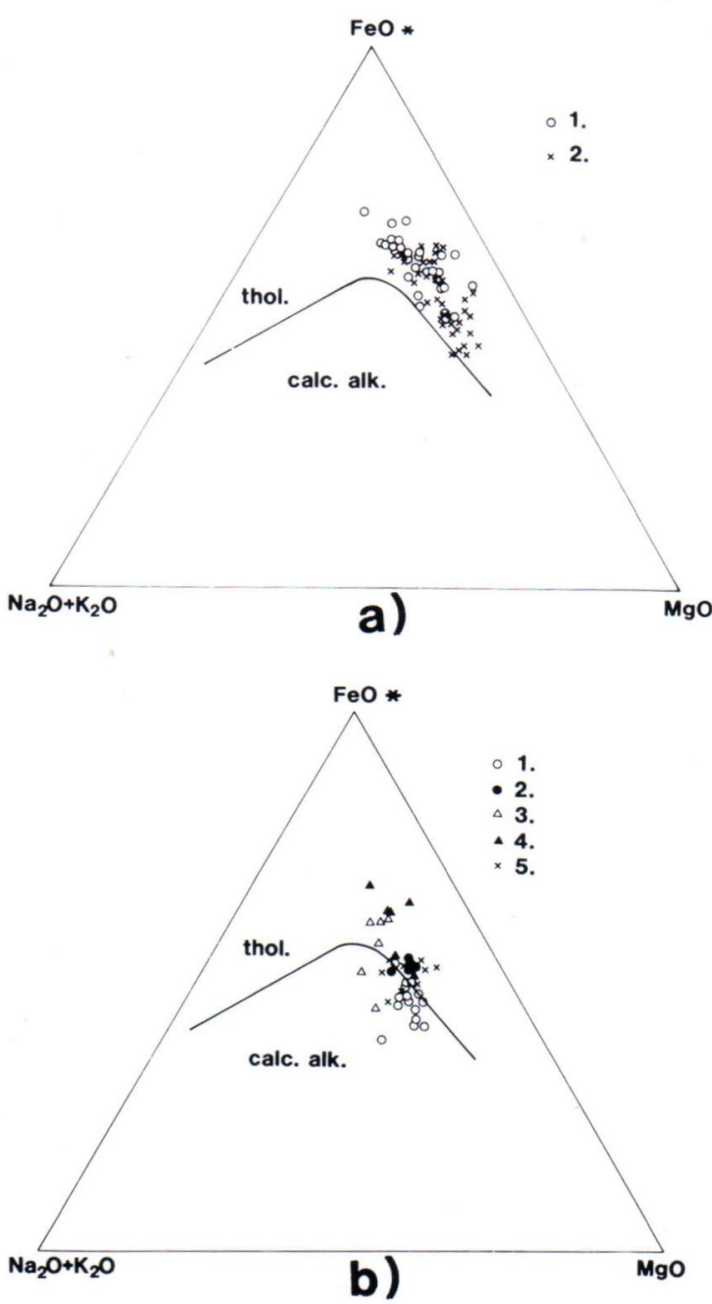

Fig. 7. AFM diagrams of rocks analysed. a. Metavolcanics from the Kiiminki schist belt. Circles correspond to samples from the Vepsä area, other samples are shown by crosses. b. 1 = Puutturi, amphibolites. 2 = Puutturi, metadiabases, 3 = Käkiperä, amphibolites. $4=$ Käkiperä, metadiabases. 5 = Kalliomaa, metagabbros. Tholeiitic/calc-alkaline boundary from Irvine and Baragar (1971).

although the samples from Vepsä include many medium-K and (among the tuffites) even high-K types (Fig. 8 a). The amphibolites of Puutturi are medium- $\mathrm{K}$ and high- $\mathrm{K}$ basalts and basaltic andesites with calc-alkaline affinities whereas the metadiabases from Puutturi are mostly medium-K basalts with tholeiitic affinities (Fig. 7 b and $8 \mathrm{~b}$ ). In the Käkiperä area both the am-
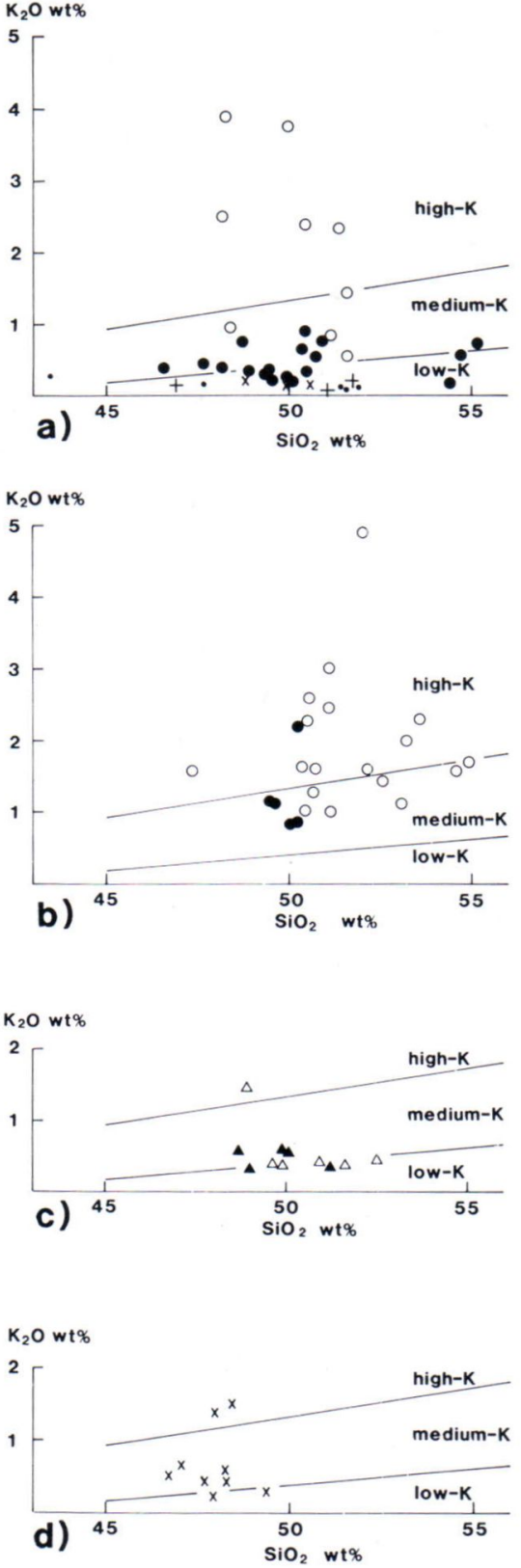

Fig. 8. $\mathrm{K}_{2} \mathrm{O} / \mathrm{SiO}_{2}$ diagrams of the rocks analysed. Based on values in Table 1 and unpublished data of Rautaruukki Oy. Sums of oxides have been calculated to $100 \%$. Low-K, medium-K and high-K fields from Gill (1981). a. Kiiminki schist belt. Points: Pyyräselkä. Crosses: Kivenselkä. Diagonal crosses: Haapamaa. Closed circles: Vepsä in general. Open circles: Tuffites of Vepsä. b. Puutturi. Open circles: Amphibolites. Closed circles: Metadiabases. c. Käkiperä. Open triangles: Amphibolites. Closed triangles: Metadiabases. $d$. Kalliomaa. 
116

Yrjö Kähkönen, Esa Mattila and Juhani Nuutilainen
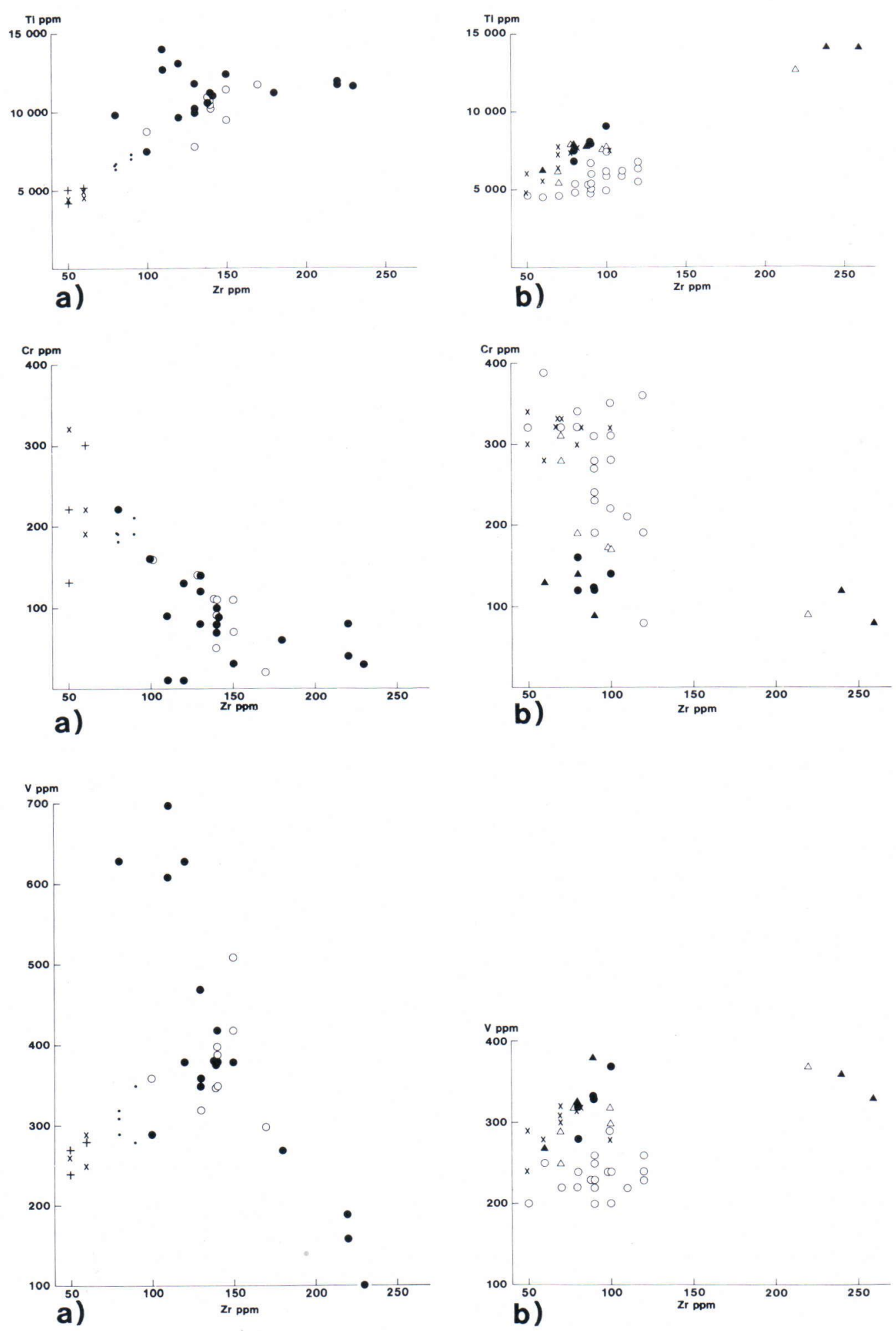

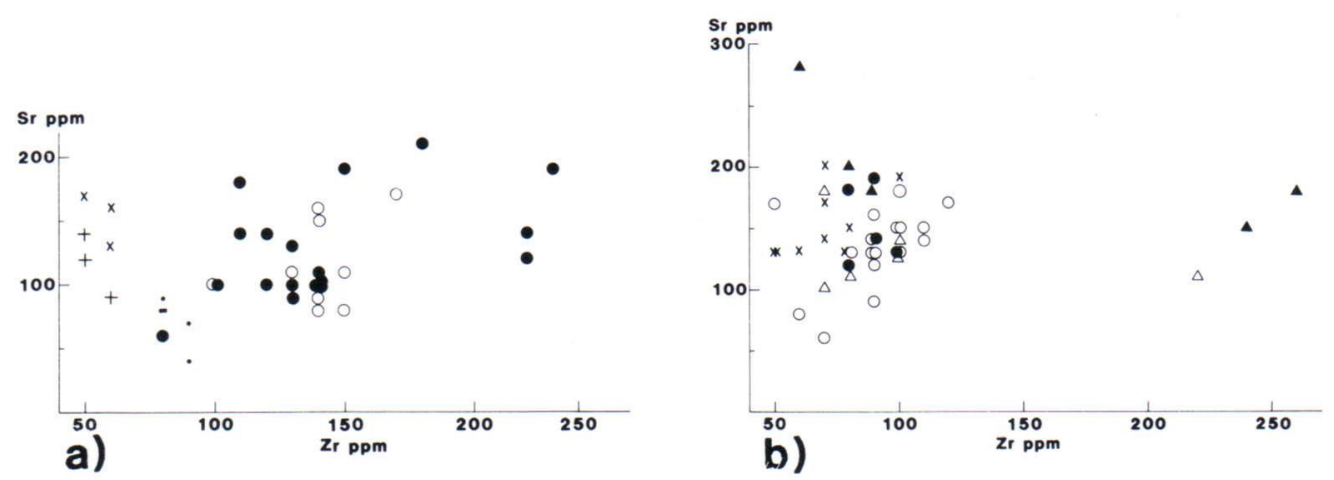

Fig. 9. $\mathrm{Ti} / \mathrm{Zr}, \mathrm{V} / \mathrm{Zr}, \mathrm{Cr} / \mathrm{Zr}$, and $\mathrm{Sr} / \mathrm{Zr}$ diagrams of the rocks analysed. Data sources and symbols as in Fig. 8. a. Kiiminki schist belt, b. Puutturi, Käkiperä and Kalliomaa.

phibolites and the metadiabases have tholeiitic affinities (Fig. 7 b) and they generally straddle on the low-K/medium-K boundary (Fig. $8 \mathrm{c}$ ). The metagabbros of Kalliomaa range from low-K to high-K rocks (Fig. $8 \mathrm{~d}$ ). According to the AFM diagram they have both tholeiitic and calcalkaline affinities but on the basis of the $\mathrm{Ti} / \mathrm{Zr}$ and $\mathrm{V} / \mathrm{Zr}$ diagrams the tholeiitic affinities are more relevant.

The differences between the calc-alkaline amphibolites of Puutturi and the tholeiitic rocks now studied are easily seen when $\mathrm{Ti}$ and $\mathrm{V}$ contents are compared at a fairly high level of $\mathrm{Zr}$ (Fig. 9). The Puutturi amphibolites have Ti < 7500 ppm (mostly $<7000$ ppm) and V $<290$ ppm (mostly $<260$ ppm) when $\mathrm{Zr}$ contents are c. $100 \mathrm{ppm}$, whereas the groups with tholeiitic affinities have $\mathrm{Ti}>7400 \mathrm{ppm}$ and $\mathrm{V}>280$ ppm at $100 \mathrm{ppm} \mathrm{Zr}$.

The $\mathrm{Cr}$ contents of all the groups decrease more or less with increasing $\mathrm{Zr}$ (Fig. 9). There are significant differences in $\mathrm{Cr}$ when the groups are compared at a relatively low level of $\mathrm{Zr}$. Thus differences in the compositions of the least evolved magmas are apparent. The amphibolites of Puutturi and the metagabbros of Kalliomaa are higher in $\mathrm{Cr}(>$ c. $260 \mathrm{ppm})$ than the metabasalts of the Kiiminki schist belt $(\mathrm{Cr}<$ c. $260 \mathrm{ppm}$ ) and the metadiabases of Puutturi and Käkiperä in particular (c. 100-160 ppm Cr), when comparisons are made at c. $75 \mathrm{ppm} \mathrm{Zr}$.
$\mathrm{Cr}$ ranges in the amphibolites of Käkiperä between 190-310 ppm at $\mathrm{Zr} 70-80 \mathrm{ppm}$. Thus they constitute an intermediate group between the higher-Cr and lower-Cr groups, and are considerably higher in $\mathrm{Cr}$ than the metadiabases with equal $\mathrm{Zr}$.

Similar differences are not apparent for $\mathrm{Ni}$ although it, too, generally decreases with increasing $\mathrm{Zr}$. The amphibolites of Puutturi range between $40-130 \mathrm{ppm} \mathrm{Ni}$ at 80 ppm $\mathrm{Zr}$ whereas the metadiabases of Puutturi and Käkiperä range between $70-130 \mathrm{ppm} \mathrm{Ni}$ at $80 \mathrm{ppm} \mathrm{Zr}$ (Table 1 and unpublished data of Rautaruukki Oy).

The $\mathrm{Sr}$ contents in the rocks studied are always $<300$ ppm and, excluding two samples, $\leq 200$ ppm. In the Kiiminki schist belt the low-K metabasalts of Pyyräselkä, Kivenselkä and Haapamaa display a decrease in $\mathrm{Sr}$ with increasing $\mathrm{Zr}$ whereas the metavolcanics of Vepsä exhibit a slight, though widely scattered, increase in $\mathrm{Sr}$ with increasing $\mathrm{Zr}$. The amphibolites of Puutturi display an increase in $\mathrm{Sr}$ with increasing $\mathrm{Zr}$ but here, too, the scattering is wide. The metadiabases of Puutturi and Käkiperä are often relatively high in $\mathrm{Sr}(180-280 \mathrm{ppm} \mathrm{Sr})$.

Differences are also seen in the REE patterns of the various groups. The samples analysed for REE from the Kiiminki schist belt (Fig. 10 a) are among the least evolved of the metabasalts of the belt. (This is deduced from their $\mathrm{Ti}, \mathrm{V}, \mathrm{Zr}$ and $\mathrm{Cr}$ contents.) They are all depleted in LREE 

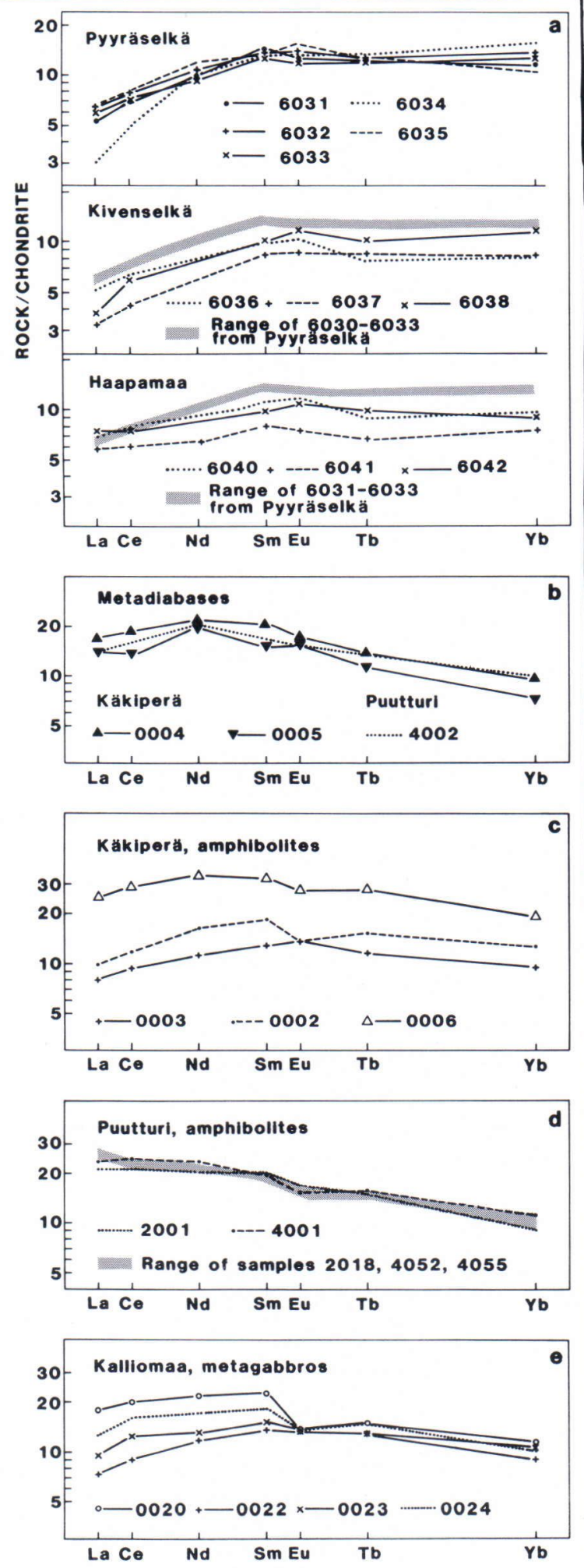

(ratio of chondrite-normalized values of $\mathrm{La}$ and $\left.\mathrm{Yb}, \mathrm{La}_{\mathrm{N}}: \mathrm{Yb}_{\mathrm{N}}=0.19-0.82\right)$ and have a flat HREE pattern $\left(\mathrm{Tb}_{\mathrm{N}}: \mathrm{Yb}_{\mathrm{N}}=0.8-1.2\right)$ at levels La $3-8 x$, Sm $8-14 x$ and $\mathrm{Yb} 7-16 \mathrm{x}$ chondrites. The patterns are not always parallel, the patterns of the samples from Haapamaa and of sample 6036 from Kivenselkä generally being flatter than those from Pyyräselkä and Kivenselkä.

The tholeiitic metadiabases of Käkiperä and Puutturi (Fig. 10 b) have LREE-enriched $\left(\mathrm{La}_{\mathrm{N}}\right.$ : $\left.\mathrm{Yb}_{\mathrm{N}}=1.4-1.9\right)$ patterns which are slightly convex-up $\left(\mathrm{La}_{\mathrm{N}}=14-17, \mathrm{Sm}_{\mathrm{N}}=15-21\right.$, $\left.\mathrm{Yb}_{\mathrm{N}}=7-10\right)$. The patterns are roughly parallel with each other and clearly different from those of the amphibolites of these two localities. The non-smooth pattern of sample 0005 is probably caused by analytical inaccuracies.

The calc-alkaline amphibolities of Puutturi (Fig. $10 \mathrm{~d})$ are all enriched in LREE $\left(\mathrm{La}_{\mathrm{N}}: \mathrm{Yb}_{\mathrm{N}}\right.$ $=2.1-3.1$ ) with La $20-30 \mathrm{x}$, Sm $18-22 \mathrm{x}$ and Yb $8-12 \times$ chondrites. These features are typical of calc-alkaline volcanics in general. The patterns have slight differences, however. In sample 2001 $\left(\mathrm{La}_{\mathrm{N}}: \mathrm{Sm}_{\mathrm{N}}=1.07\right)$, for example, the pattern between $\mathrm{La}$ and $\mathrm{Sm}$ is flatter than in the other four samples $\left(\mathrm{La}_{\mathrm{N}}: \mathrm{Sm}_{\mathrm{N}}=1.23-1.44\right)$.

Among the tholeiitic amphibolites of Käkiperä (Fig. $10 \mathrm{c}$ ) sample 0003 is less evolved (lower in $\mathrm{REE}, \mathrm{Zr}$, Ti and $\mathrm{V}$; higher in $\mathrm{Cr}$ and $\mathrm{Ni}$ ) than sample 0002. The REE patterns of these two samples are crossly parallel; both are convex-up and slightly depleted in LREE $\left(\mathrm{La}_{\mathrm{N}}: \mathrm{Yb}_{\mathrm{N}}=\right.$ $0.78-0.82)$ at levels $\mathrm{La} 8-10 \mathrm{x}, \mathrm{Sm} 12--18 \mathrm{x}$ and $\mathrm{Yb} 9-13 \times$ chondrites. The Eu minimum in sample 0002 is indisputable. The highly evolved amphibolite 0006 (high in REE, Ti and $\mathrm{Zr}$ ) also has a convex-up REE pattern $\left(\mathrm{La}_{\mathrm{N}}=24, \mathrm{Sm}_{\mathrm{N}}\right.$ $\left.=32, \mathrm{Yb}_{\mathrm{N}}=14\right)$ but it deviates from the two considered above in its slight enrichment in

Fig. 10. Chondrite-normalized REE-patterns of the rocks studied. Chondrite: Leedey 6 (values of Masuda et al. 1973, divided by factor 1.2; see Jahn et al. 1980). a. Metabasalts of the Kiiminki schist belt; b. Metadiabases of Käkiperä and Puutturi; c. Amphibolites of Käkiperä; d. Amphibolites of Puutturi; e. Metagabbros of Kalliomaa. 
LREE $\left(\mathrm{La}_{\mathrm{N}}: \mathrm{Yb}_{\mathrm{N}}=1.3\right)$. Note also that it lacks a distinct $\mathrm{Eu}$ minimum.

The metagabbros of Kalliomaa (Fig. 10 e) display both LREE-depleted $\left(\mathrm{La}_{\mathrm{n}}: \mathrm{Yb}_{\mathrm{N}}=0.8-\right.$ 0.9 for medium-K samples 0022 and 0023 ) and slightly LREE-enriched $\left(\mathrm{La}_{\mathrm{N}}: \mathrm{Yb}_{\mathrm{N}}=1.2-1.6\right.$ for high-K samples 0020 and 0024) patterns. They are roughly parallel from $\mathrm{Tb}$ to $\mathrm{Yb}$ and define a narrow range (e.g. $\left.\mathrm{Yb}_{\mathrm{N}}=9-11\right)$. Another common feature is the regular increase from $\mathrm{La}_{\mathrm{N}}(7-18)$ to $\mathrm{Sm}_{\mathrm{N}}(12-22)$. The Eu minima become deeper concurrently with the increase in LREE and K. The non-smooth pattern of sample 0022 is probably due to analytical inaccuracies.

\section{Tectonomagmatic and petrogenetic discussion}

\section{General}

Trace elements are a valuable tool for studies on the evolution of igneous rocks (e.g. Allégre and Hart 1978, Hanson 1980). They also give clues to the original tectonic setting of volcanic rocks (e.g. Pearce and Cann 1973, Pearce 1982 and 1983).

The present paper examines the possible effects of alterations and sedimentary mixing, and the feasibility of comagmatic relations within (and partly between) the groups. The discussion of consanguinities is based on the following features (see e.g. Hanski 1983 for mineral/melt partition coefficients or D-values): (1) In basaltic rocks the dominant crystallizing minerals are olivine \pm pyroxenes \pm plagioclase \pm Cr-spinel \pm magnetite. (2) $\mathrm{Zr}$ contents increase with progressive fractionation. (3) $\mathrm{Cr}$ contents decrease when $\mathrm{Cr}$-spinel and/or pyroxenes fractionate. (4) $\mathrm{Ni}$ contents decrease when olivine in particular (and/or pyroxenes and/or magnetite) fractionate. (5) $\mathrm{Sr}$ contents decrease when plagioclase fractionates. (6) V contents increase when olivine and/or orthopyroxene and/or plagioclase fractionate. (7) The level of REE increases with increasing fractionation but the shape of chondritenormalized patterns does not significantly change in basaltic systems. Eu is a major exception because, in systems with low oxygen fugacity, it can become relatively depleted from residual liquids if plagioclase is fractionated. (8) When a combination of minerals fractionates the changes are determined by relative proportions of the phases.

The rocks now being discussed are mostly basaltic. Thus they are ultimately derived by partial melting of ultramafic sources, i.e. mantle. Primary melts in equilibrium with the mantle have $\mathrm{FeO}^{*}$ : MgO-ratios $0.48-0.90$ and $\mathrm{Cr}$ contents about $400-800$ ppm (see Basaltic Volcanism Study Project 1981, Table 1.4.2.2.). The volcanics studied have $\mathrm{FeO}^{*}$ : $\mathrm{MgO}$ ratios exceeding unity and $\mathrm{Cr}$ contents of $300-400 \mathrm{ppm}$ at maximum. Therefore, even the most primitive of them are not primary melts but their compositions have been influenced by differentiation processes.

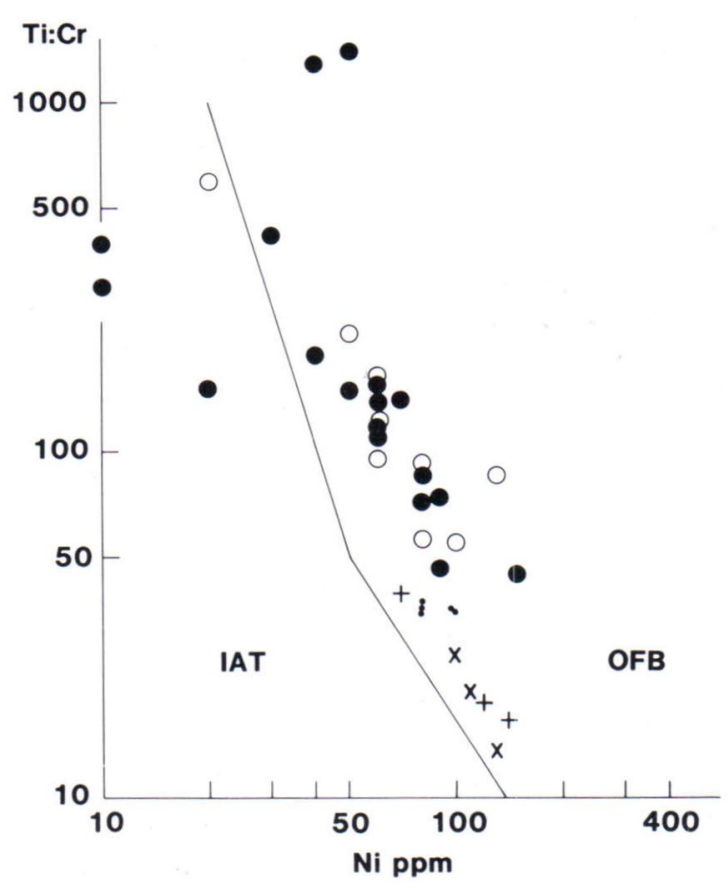

Fig. 11. (Ti:Cr)/Ni diagram of the metabasalts from Kiiminki schist belt. Symbols and data sources as in Fig. 8a. The boundary between IAT (island arc tholeiites) and OFB (ocean floor basalts) is from Beccaluva et al. (1979). Note that the three filled circles at $10-20 \mathrm{ppm} \mathrm{Ni}$ are the highly evolved $\left(\mathrm{SiO}_{2} 54-55 \%, \mathrm{Zr} 220-230 \mathrm{ppm}\right)$ rocks of Vepsä. 
Table 1. Representative major and trace element analyses of the rocks studied. Major elements: weight $\%$. Minor elements: ppm. $\mathrm{FeO}^{*}$ : total $\mathrm{Fe}$ as $\mathrm{FeO}$. »Total» contains $\mathrm{Fe}$ as $\mathrm{Fe}_{2} \mathrm{O}_{3}$ and trace elements as oxides.

\begin{tabular}{|c|c|c|c|c|c|c|c|c|c|c|c|c|c|c|c|c|}
\hline & \multicolumn{4}{|c|}{ Pyyräselkä } & \multicolumn{4}{|c|}{ Kivenselkä } & \multicolumn{3}{|c|}{ Haаpamaа } & \multicolumn{5}{|l|}{ Vepsä } \\
\hline & $\begin{array}{c}7381- \\
6031\end{array}$ & $\begin{array}{l}7381- \\
6032\end{array}$ & $\begin{array}{c}7381- \\
6033\end{array}$ & $\begin{array}{c}7381- \\
6034\end{array}$ & $\begin{array}{l}7381- \\
6035\end{array}$ & $\begin{array}{c}7381- \\
6036\end{array}$ & $\begin{array}{c}7381- \\
6037\end{array}$ & $\begin{array}{c}7381- \\
6038\end{array}$ & $\begin{array}{c}7381- \\
6040\end{array}$ & $\begin{array}{c}7381- \\
6041\end{array}$ & $\begin{array}{l}7381- \\
6042\end{array}$ & $\begin{array}{c}7281- \\
2153\end{array}$ & $\begin{array}{l}7281- \\
2154\end{array}$ & $\begin{array}{l}7281- \\
2178\end{array}$ & $\begin{array}{c}7281- \\
2182\end{array}$ & $\begin{array}{c}7281- \\
2251\end{array}$ \\
\hline $\mathrm{SiO}_{2}$ & 51.27 & 50.33 & 49.89 & 46.57 & 42.37 & 51.06 & 50.00 & 45.02 & 47.04 & 48.86 & 48.20 & 54.40 & 49.02 & 48.01 & 47.61 & 54.69 \\
\hline $\mathrm{TiO}_{2}$ & 1.11 & 1.10 & 1.07 & 1.17 & 1.22 & 0.85 & 0.71 & 0.87 & 0.83 & 0.73 & 0.76 & 1.98 & 1.70 & 1.70 & 2.33 & 1.95 \\
\hline $\mathrm{Al}_{2} \mathrm{O}_{3}$ & 12.72 & 13.60 & 12.39 & 13.40 & 13.45 & 13.21 & 13.93 & 14.31 & 14.13 & 14.38 & 13.69 & 13.77 & 12.77 & 14.42 & 13.52 & 13.01 \\
\hline $\mathrm{FeO}^{*}$ & 12.10 & 11.90 & 12.45 & 15.12 & 16.95 & 12.37 & 11.24 & 13.28 & 12.10 & 10.20 & 11.12 & 15.20 & 14.56 & 14.75 & 16.06 & $\begin{array}{ll}5 & 14.97\end{array}$ \\
\hline $\mathrm{MnO}$ & 0.22 & 0.20 & 0.21 & 0.25 & 0.27 & 0.21 & 0.19 & 0.23 & 0.22 & 0.21 & 0.19 & 0.22 & 0.21 & 0.16 & 0.23 & 0.21 \\
\hline $\mathrm{MgO}$ & 7.34 & 6.68 & 7.44 & 8.31 & 8.36 & 6.89 & 8.32 & 9.02 & 7.34 & 7.73 & 7.88 & 4.87 & 6.23 & 8.49 & 5.36 & 4.38 \\
\hline $\mathrm{CaO}$ & 8.68 & 8.74 & 9.51 & 8.07 & 10.38 & 10.11 & 9.20 & 10.19 & 10.79 & 11.82 & 9.19 & 4.80 & 8.92 & 5.38 & 8.29 & 5.36 \\
\hline $\mathrm{Na}_{2} \mathrm{O}$ & 3.55 & 3.25 & 2.27 & 2.60 & 1.80 & 2.09 & 2.78 & 1.15 & 2.04 & 2.12 & 2.55 & 2.20 & 2.35 & 1.09 & 3.22 & 2.37 \\
\hline $\mathrm{K}_{2} \mathrm{O}$ & 0.12 & 0.08 & 0.12 & 0.17 & 0.27 & 0.21 & 0.08 & 0.14 & 0.19 & 0.15 & 0.13 & 0.18 & 0.18 & 2.49 & 0.45 & 0.57 \\
\hline $\mathrm{P}_{2} \mathrm{O}_{5}$ & 0.11 & 0.14 & 0.06 & 0.05 & 0.09 & 0.08 & 0.07 & 0.06 & 0.08 & 0.08 & 0.07 & 0.35 & 0.21 & 0.24 & 0.18 & 0.36 \\
\hline Total & 98.77 & 97.62 & 97.04 & 97.68 & 97.47 & 98.65 & 97.94 & 95.95 & 96.34 & 97.76 & 95.30 & 99.96 & 98.02 & 99.60 & 99.87 & $7 \quad 99.97$ \\
\hline $\mathrm{Zr}$ & 80 & 80 & 80 & 90 & 90 & 50 & 50 & 60 & 60 & 50 & 60 & 220 & 130 & 140 & 110 & 220 \\
\hline $\mathrm{Cr}$ & 190 & 190 & 180 & 190 & 210 & 130 & 220 & 300 & 190 & 320 & 220 & 80 & 120 & 110 & 10 & 40 \\
\hline $\mathrm{Ni}$ & 100 & 100 & 80 & 80 & 80 & 70 & 120 & 140 & 100 & 130 & 110 & 20 & 80 & 80 & 50 & 10 \\
\hline V & 320 & 290 & 310 & 350 & 280 & 270 & 240 & 280 & 290 & 260 & 250 & 190 & 360 & 390 & 700 & 160 \\
\hline $\mathrm{Cu}$ & 20 & 80 & 20 & 90 & 350 & 80 & 40 & 0 & 70 & 100 & 50 & 70 & 50 & 130 & 170 & 50 \\
\hline $\mathrm{Zn}$ & 120 & 110 & 110 & 140 & 130 & 100 & 90 & 120 & 100 & 90 & 80 & 120 & 150 & 170 & 140 & 170 \\
\hline $\mathrm{Sr}$ & 80 & 80 & 90 & 70 & 40 & 110 & 140 & 90 & 160 & 170 & 130 & 140 & 90 & 90 & 180 & 120 \\
\hline $\mathrm{La}$ & 1.65 & 2.0 & 1.91 & 0.94 & 2.1 & 1.59 & 1.01 & 1.18 & 2.2 & 1.8 & 2.3 & & & & & \\
\hline $\mathrm{Ce}$ & 5.6 & 6.2 & 5.8 & 4.0 & 6.4 & 5.1 & 3.4 & 4.7 & 6.4 & 4.9 & 6.0 & & & & & \\
\hline $\mathrm{Nd}$ & 6.0 & 6.2 & 5.7 & 6.2 & 7.2 & - & - & - & 5.4 & 3.8 & - & & & & & \\
\hline Sm & 2.7 & 2.6 & 2.4 & 2.4 & 2.5 & 1.87 & 1.61 & 1.88 & 2.1 & 1.54 & 1.84 & & & & & \\
\hline $\mathrm{Eu}$ & 0.88 & 0.99 & 0.87 & 0.96 & 1.09 & 0.75 & 0.63 & 0.84 & 0.83 & 0.54 & 0.77 & & & & & \\
\hline $\mathrm{Tb}$ & 0.58 & 0.60 & 0.58 & 0.64 & 0.60 & 0.37 & 0.39 & 0.48 & 0.42 & 0.31 & 0.46 & & & & & \\
\hline $\mathrm{Yb}$ & 2.5 & 2.8 & 2.6 & 3.3 & 2.2 & 1.71 & 1.73 & 2.4 & 1.97 & 1.53 & 1.86 & & & & & \\
\hline
\end{tabular}

Major and trace elements (excluding REE) by XRF from pressed rock powder briquettes at Raahe laboratory of Rautaruukki Oy. REE by instrumental neutron activation analysis at the Reactor Laboratory of the Technical Research Centre of Finland (Rosenberg 1977). A list of all analyses used is available from the authors on request. See Appendix I for petrography.

\section{The metabasalts of the Kiiminki schist belt}

The low-K pillowed metabasalts of the main volcanic period of the Kiiminki schist belt bear a close resemblance to present-day N-type midocean ridge basalts (MORB) in their LREEdepleted patterns (Fig. 10) and ( $\mathrm{Ti}: \mathrm{Cr}$ )/Ni ratios (Fig. 11). The common occurrence of tuffites and greywackes, however, suggests, that the basin was neither very large nor very deep because the pillowed basalts are often amygdaloidal.

The low-K metabasalts of Pyyräselkä, Kivenselkä and Haapamaa exhibit increases in $\mathrm{Ti}$ and $\mathrm{V}$ and general decreases in $\mathrm{Ni}, \mathrm{Cr}$ and $\mathrm{Sr}$ with increasing $\mathrm{Zr}$ so that the metabasalts of
Pyyräselkä are highest in Zr. The Pyyräselkä metabasalts are on the whole also higher in REE (especially from $\mathrm{Sm}$ to $\mathrm{Yb}$ ) than those of Kivenselkä and Haapamaa, and their REE patterns (especially samples 6031-6033) are parallel with the patterns of samples 6037 and 6038 from Kivenselkä. Thus it is possible that the metabasalts of Pyyräselkä are derived from magmas with compositions resembling those in samples 6037 and 6038 through fractional crystallization of mafic phases and plagioclase. Calculations using the Rayleigh equation suggest $40 \%$ fractionation of olivine, clinopyroxene and plagioclase at ratios of $15: 15: 70$ (Appendix II). The model suggested gives fairly good agreement between 
Table 1 (cont.)

\begin{tabular}{|c|c|c|c|c|c|c|c|c|c|c|c|c|c|c|c|}
\hline & \multicolumn{5}{|c|}{ B. Puutturi } & \multicolumn{4}{|c|}{ C. Käkiperä } & \multicolumn{6}{|c|}{ D. Kalliomaa } \\
\hline & Amphit & polites & & & & $\begin{array}{l}\text { Meta- } \\
\text { dia- } \\
\text { base }\end{array}$ & $\mathrm{Amr}$ & phibolit & & $\begin{array}{l}\text { Metadia } \\
\text { bases }\end{array}$ & & Metaga & bbros & & \\
\hline & $\begin{array}{l}7281- \\
2001\end{array}$ & $\begin{array}{l}7281- \\
2018\end{array}$ & $\begin{array}{l}7281- \\
4052\end{array}$ & $\begin{array}{l}7281- \\
4055\end{array}$ & $\begin{array}{l}7281- \\
4001\end{array}$ & $\begin{array}{l}7183- \\
4002\end{array}$ & $\begin{array}{l}7383- \\
0002\end{array}$ & $\begin{array}{c}7383- \\
0003\end{array}$ & $\begin{array}{c}7383- \\
0006\end{array}$ & $\begin{array}{l}7383- \\
0004\end{array}$ & $\begin{array}{l}7383- \\
0005\end{array}$ & $\begin{array}{c}7383- \\
0020\end{array}$ & $\begin{array}{c}7383- \\
0022\end{array}$ & $\begin{array}{c}7383- \\
0023\end{array}$ & $\begin{array}{l}7383- \\
0024\end{array}$ \\
\hline $\mathrm{iO}_{2}$ & 53.06 & 53.93 & 50.56 & 50.99 & 48.64 & 48.82 & 51.16 & 50.15 & 48.47 & 46.63 & 47.19 & 45.32 & 44.01 & 42.82 & 44.94 \\
\hline $\mathrm{TiO}_{2}$ & 1.02 & 0.89 & 1.06 & 1.13 & 0.85 & 1.13 & 1.32 & 1.04 & 2.12 & 1.32 & 1.04 & 0.79 & 1.01 & 0.93 & 1.07 \\
\hline $\mathrm{Al}_{2} \mathrm{O}_{3}$ & 13.99 & 13.98 & 14.02 & 13.83 & 13.54 & 13.00 & 14.68 & 16.41 & 12.06 & 12.78 & 14.15 & 14.26 & 13.61 & 13.65 & 15.58 \\
\hline $\mathrm{FeO}^{*}$ & 10.87 & 9.32 & 11.03 & 11.63 & 10.65 & 12.11 & 10.80 & 10.96 & 14.89 & 12.98 & 11.33 & 10.78 & 11.36 & 9.59 & 9.49 \\
\hline $\mathrm{MnO}$ & 0.20 & 0.22 & 0.26 & 0.22 & 0.17 & 0.25 & 0.39 & 0.33 & 0.31 & 0.21 & 0.18 & 0.20 & 0.28 & 0.49 & 0.18 \\
\hline $\mathrm{MgO}$ & 7.29 & 7.67 & 7.38 & 6.45 & 7.46 & 6.92 & 5.17 & 5.58 & 5.57 & 6.79 & 6.86 & 7.60 & 7.84 & 6.59 & 6.53 \\
\hline $\mathrm{CaO}$ & 8.43 & 7.89 & 10.26 & 10.23 & 9.46 & 9.37 & 7.77 & 9.84 & 8.59 & 9.72 & 11.11 & 9.04 & 12.40 & 12.68 & 10.14 \\
\hline $\mathrm{Na}_{2} \mathrm{O}$ & 2.35 & 2.01 & 1.93 & 2.54 & 3.20 & 3.19 & 4.13 & 3.86 & 2.63 & 3.04 & 2.70 & 2.58 & 1.68 & 2.39 & 3.00 \\
\hline $\mathrm{K}_{2} \mathrm{O}$ & 1.12 & 1.55 & 1.59 & 0.99 & 0.97 & 0.81 & 0.44 & 0.38 & 0.38 & 0.58 & 0.32 & 1.41 & 0.51 & 0.59 & 1.30 \\
\hline $\mathrm{P}_{2} \mathrm{O}_{5}$ & 0.02 & 0.12 & 0.12 & 0.12 & 0.09 & 0.09 & 0.12 & 0.06 & 0.18 & 0.10 & 0.08 & 0.14 & 0.11 & 0.09 & 0.11 \\
\hline Total & 99.93 & 98.81 & 99.67 & 99.67 & 96.43 & 97.27 & 97.49 & 97.18 & 97.15 & 95.80 & 96.42 & 93.60 & 94.29 & 91.12 & 93.69 \\
\hline $\mathrm{Zr}$ & 100 & 90 & 120 & 120 & 90 & 80 & 80 & 70 & 220 & 80 & 60 & 50 & 50 & 60 & 70 \\
\hline $\mathrm{Cr}$ & 220 & 270 & 190 & 80 & 240 & 160 & 190 & 310 & 90 & 140 & 130 & 300 & 340 & 280 & 330 \\
\hline $\mathrm{Ni}$ & 70 & 50 & 90 & 70 & 100 & 90 & 90 & 170 & 30 & 130 & 110 & 120 & 140 & 140 & 150 \\
\hline V & 240 & 230 & 240 & 260 & 230 & 280 & 320 & 290 & 370 & 320 & 270 & 240 & 290 & 280 & 310 \\
\hline $\mathrm{Cu}$ & 50 & 10 & 70 & 110 & 100 & 50 & 30 & 30 & 200 & 150 & 90 & 40 & 50 & 50 & 90 \\
\hline $\mathrm{Zn}$ & 150 & 180 & 130 & 120 & 90 & 110 & 120 & 80 & 110 & 100 & 90 & 120 & 120 & 110 & 100 \\
\hline $\mathrm{Sr}$ & 150 & 120 & 170 & 140 & 140 & 120 & 110 & 180 & 110 & 200 & 280 & 130 & 130 & 130 & 150 \\
\hline $\mathrm{La}$ & 6.5 & 7.7 & 9.0 & 8.9 & 7.3 & 4.3 & 3.1 & 2.5 & 7.7 & 5.2 & 4.4 & 5.6 & 2.3 & 3.0 & 3.9 \\
\hline $\mathrm{Ce}$ & 17 & 16 & 18 & 20 & 20 & 13 & 9.3 & 7.5 & 23 & 15 & 11 & 16 & 7.2 & 10 & 13 \\
\hline $\mathrm{Nd}$ & 12 & 13 & 13 & 12 & 14 & 12 & 9.7 & 6.8 & 20 & 13 & 12 & 13 & 7.0 & 7.4 & 10 \\
\hline $\mathrm{Sm}$ & 3.7 & 3.4 & 3.8 & 4.0 & 3.6 & 3.2 & 3.5 & 2.4 & 6.2 & 3.9 & 2.9 & 4.3 & 2.6 & 2.9 & 3.5 \\
\hline $\mathrm{Eu}$ & 1.2 & 1.0 & 1.2 & 1.2 & 1.1 & 1.1 & 0.97 & 0.98 & 2.0 & 1.2 & 1.1 & 0.91 & 0.95 & 0.98 & 0.98 \\
\hline $\mathrm{Tb}$ & 0.68 & 0.64 & 0.64 & 0.73 & 0.73 & 0.62 & 0.71 & 0.54 & 1.3 & 0.65 & 0.53 & 0.70 & 0.62 & 0.63 & 0.68 \\
\hline $\mathrm{Yb}$ & 1.9 & 2.0 & 1.9 & 2.5 & 2.3 & 2.1 & 2.6 & 2.0 & 3.9 & 2.0 & 1.51 & 2.3 & 1.9 & 2.2 & 2.1 \\
\hline
\end{tabular}

the observed and calculated derivative compositions but there are some uncertainties e.g.: (1) the D-values vary to some degree (e.g. $\mathrm{D}_{\mathrm{Cr}}^{\mathrm{ol}}$, which often exceeds 0.2 , see compilation of Hanski 1983). (2) The role of Cr-spinel was not considered. (3) $\mathrm{C}_{0}$ is partly from a single sample and partly from averages. (4) $\mathrm{Sr}$ is probably more mobile than, say, $\mathrm{Zr}$. (5) Major element modelling was not done. Besides these, in MORB, low pressure fractionation is dominated by plagioclase and olivine.

Although largely resembling samples 6037 and 6038 in Ti, V, Cr, Ni, Sr and Zr, sample 6036 (from Kivenselkä) and samples 6040-6042 (from Haapamaa) are not plausible parents for the fractionation described above because of their crossing REE patterns. Sample 6036, is further relatively low in $\mathrm{Cr}$. These features may be due to heterogeneities in the mantle or to dynamic melting (see e.g. Basaltic Volcanism Study Project 1981, p. 154). Using calculations like those in Appendix II we find that samples 6040 and 6042 from Haapamaa can be derived from sample 6041 by c. $20 \%$ fractionation of $70-80 \%$ plagioclase, $20 \%$ olivine and some $\mathrm{Cr}$-spinel (spinel to explain the notably steep decrease in Cr.) It is admitted that these ratios do not conform with the observed relics of phenocrysts (see Appendix I).

The REE patterns of samples 6034 and 6035 from Pyyräselkä cross each other and the narrow range of the patterns of samples $6031-6033$. In sample 6035 these incongruencies are probably due to alterations in pillow matrix (note here the 
slight increase in $\mathrm{K}$ and also the low $\mathrm{Sr}$ ). Alteration in a small pillow is suggested for sample 6034.

In any case, the consistent LREE depletions in the low-K metabasalts of Kiiminki schist belt indicate that the mantle from which they melted was depleted in LREE. The depletion involved quite a large area because LREE depleted basic Karelian volcanics are known from the Puolanka and Kemi areas, about $60 \mathrm{~km} \mathrm{E}$ and $120 \mathrm{~km} \mathrm{NW}$, respectively, of the present study area (Laajoki 1975, Huhma 1984).

The tuffites of Vepsä often have high potassium contents but otherwise resemble the other metavolcanics of Vepsä in $\mathrm{Ti}, \mathrm{V}, \mathrm{Cr}, \mathrm{Ni}, \mathrm{Sr}$ and $\mathrm{Zr}$. They (like the metabasalts of the schist belt in general) contain less than $0.13 \% \mathrm{P}$ (Table 1 and unpublished data by Rautaruukki Oy). Because $\mathrm{P}$ contents in alkaline and shoshonitic basalts are often higher (e.g. $0.19-0.28 \%$ in Pearce 1982) the high-K nature of these tuffites is probably not a primary feature of magma. The tuffites have apparently been mixed with pelitic material ( $\mathrm{P}$ is below $0.13 \%$ in various clays and shales of Koritnig 1978) with high contents of $\mathrm{K}$ but the mixing did not cause significant disturbances in the contents of $\mathrm{Ti}, \mathrm{V}, \mathrm{Cr}, \mathrm{Ni}, \mathrm{Sr}$ and $\mathrm{Zr}$.

The cross distribution of the metavolcanics of Vepsä on the $\mathrm{Ti} / \mathrm{Zr}, \mathrm{V} / \mathrm{Zr}, \mathrm{Cr} / \mathrm{Zr}$ and $\mathrm{Ni} / \mathrm{Zr}$ diagrams (including the changes in slopes and the location on the continuations of the trends of Pyyräselkä, Kivenselkä and Haapamaa) could be attributed to the continued fractionation of mafic phases and the commencement of fractionation of magnetite at $130-150 \mathrm{ppm} \mathrm{Zr}$. The behaviour of $\mathrm{Sr}$, however, does not permit fractionation of plagioclase at Vepsä, and comagmatic relations with, say, the metabasalts from Pyyräselkä are not plausible. Note also that the nontuffitic rocks of Vepsä are partly of medium-K, not low-K, type. A third feature to be noted is the occurrence of high- $\mathrm{V}$, high-Ti and low- $\mathrm{Cr}$ metabasalts at $110-120 \mathrm{ppm} \mathrm{Zr}$. All in all these features suggest that at Vepsä we have numerous separate magma bodies differing slightly in composition. The diversities are emphasized by mixing with sediments, by hydrothermal alterations and possibly by assimilation with the crust. (Remember that the metabasalts of Vepsä belong to the lower volcanic period of the schist belt.) The highly evolved rocks of Vepsä (high $\mathrm{Zr}, \mathrm{SiO}_{2}=$ $54-55 \%$, low $\mathrm{V}$ ) indicate considerable fractionation of magnetite in any case.

\section{The metadiabases of Puutturi and Käkiperä}

The metadiabases are associated with rifting of a continent in the early Proterozoic and probably predated the metabasalts that erupted into the basin now constituting the Kiiminki schist belt. The metadiabases differ from the metabasalts of the schist belt in being generally lower in $\mathrm{Cr}$ at c. $70 \mathrm{ppm} \mathrm{Zr}$, and in displaying REE patterns enriched in LREE. Thus these two Karelian groups of basaltic rocks are not comagmatic. Questions beyond the scope of the present study are whether the LREE enrichments in the metadiabases are features of the mantle, products of contamination by the continental crust or due to some other cause (see e.g. the articles in the book by Hawkesworth and Norry 1983 for relevant discussions).

The metadiabases of Puutturi are higher in $\mathrm{K}$ than those of Käkiperä. The two groups have, however, numerous characteristics in common, e.g. tholeiitic affinities, low $\mathrm{Cr}$ at low level of $\mathrm{Zr}$ and almost parallel REE patterns. These features suggest that they have a largely, though not totally, common origin. The two highly evolved metadiabases of Käkiperä (240-260 ppm Zr) are exceptions because their $\mathrm{Cr}$ and $\mathrm{Sr}$ contents are roughly the same as those in metadiabases with 60-100 ppm $\mathrm{Zr}$. Thus they are hardly comagmatic with the typical metadiabases discussed above. They may even be Archean in age because diabasic rocks occurring among Archean metavolcanics can be either Proterozoic or Archean (possibly feeder dykes and sills in the latter case). 


\section{The amphibolites of Käkiperä}

Although the amphibolites of Käkiperä have tholeiitic affinities, their REE patterns and $\mathrm{Cr}$ contents distinguish them from the Karelian metadiabases that cut these polyphase-deformed schists. Fractionation of mafic phases could largely explain the steep decreases in $\mathrm{Cr}$ and $\mathrm{Ni}$ with increasing $\mathrm{Zr}$ and the nearly parallel REE patterns in samples 0002 and 0003 . However, the role of plagioclase would pose difficulties. $\mathrm{Sr}$ tends to display slight increase from $100 \mathrm{ppm}$ to $140 \mathrm{ppm}$ when $\mathrm{Zr}$ increases from $70 \mathrm{ppm}$ to $100 \mathrm{ppm}$ but sample 0003 with $180 \mathrm{ppm} \mathrm{Sr}$ at $70 \mathrm{ppm} \mathrm{Zr}$ is an exception. So, fractionation of plagioclase is not plausible for the majority of the amphibolites of Käkiperä. There is no Eu anomaly in sample 0003 but a distinct Eu minimum occurs in sample 0002. At first sight, sample 0002 could be derived from sample 0003 by fractionation of plagioclase (behaviours of $\mathrm{Sr}$ and $\mathrm{Eu})$ and mafic phases ( $\mathrm{Cr}, \mathrm{Ni})$.

Approximations on the degree of fractional crystallization implied (based on calculations presuming bulk $\overline{\mathrm{D}}$ for $\mathrm{Zr}, \mathrm{La}, \mathrm{Sm}, \mathrm{Tb}$ and $\mathrm{Yb}$ to approach zero and use the contents of these elements in samples 0002 and 0003 ) give $F$ values (Appendix II) between $0.7-0.9$. Fractionations like these are too small to be able to produce the decrease in $\mathrm{Sr}$ and the large negative Eu anomaly in sample 0002. For example if $F$ were 0.7 and $\mathrm{D}_{\mathrm{Sr}}$ for plagioclase were 2.2 , the Rayleigh equation would suggest that the solid residue should contain about $100 \%$ plagioclase and no room would be left for pyroxenes and olivine (to explain the decreases in $\mathrm{Cr}$ and $\mathrm{Ni}$ ). Thus fractional crystallization alone can hardly explain the changes in the chemical composition of the amphibolites of Käkiperä. This holds true for sample 0006, too, because it displays LREE enrichment (whereas samples 0002 and 0003 LREE depletion) and is relatively high in $\mathrm{K}$.

\section{The metagabbros of Kalliomaa}

The basic rocks of Kalliomaa differ from the volcanic rocks studied in being metagabbros. They do not generally contain more amphibole (which occurs partly as relics after pyroxene phenocrysts) than the lower-Cr metadiabases of Puutturi and Käkiperä (Appendix I), and sample 0022 with 70 vol. $\%$ amphibole (340 ppm Cr) does not contain significantly more $\mathrm{Cr}$ than do samples with $40-50$ vol. \% amphibole (280330 ppm Cr). Therefore, the relatively high $\mathrm{Cr}$ contents in the metagabbros are not obviously due to accumulation of mafic silicates, but rather are a primary feature of magma.

The chemical characteristics of the metagabbros are difficult to explain by fractional crystallization (ranges of $\mathrm{Zr}, \mathrm{Cr}$ and HREE are narrow, but ranges in $\mathrm{K}$ and LREE are wider) or by variable degrees of partial melting (liquids of lowest percentage of fusion should leave a residue rich in plagioclase to produce Eu anomalies). Since mineral effects are not apparent either (proper minerals are not abundant enough), mixing of magmas or early alteration would seem to be the more plausible processes.

\section{The amphibolites of Puutturi}

The amphibolites of Puutturi have indisputable calc-alkaline affinities. In terms of plate tectonics calc-alkaline volcanics are typically associated with converging plate margins. Whether this is the case for the amphibolites of Puutturi, too, is not relevant in the present context; important is the fact that they differ totally from basic rocks in Karelian sequences, which regularly have tholeiitic affinities (Pekkarinen 1979, Honkamo 1980, Perttunen 1983, present study).

Geological mapping and geophysical data suggest that the amphibolites of Puutturi belong to the basement underlying the Kiiminki schist belt. Further, though not absolute, support for their Archean age is provided by their high $\mathrm{Cr}$ and low Sr contents. Cr averages for Archean metabasalts with variably defined calc-alkaline affinities range between 175 and 250 ppm (Condie 1976, 1981; Goodwin 1977). Although the 
range of $\mathrm{Cr}$ averages in Recent calc-alkaline basalts (65-378 ppm, Ewart 1982 Appendix 2) includes the range of Archean $\mathrm{Cr}$ averages the Puutturi amphibolites have higher average $\mathrm{Cr}$ (about $280 \mathrm{ppm}$ ) than do Recent calc-alkaline metabasalts on the whole. Recent calc-alkaline basalts have $\mathrm{Sr}$ averages exceeding $300 \mathrm{ppm}$ (Ewart 1982, Pearce 1982) whereas the Sr averages in their Archean equivalents are below 200 ppm (Condie 1976, 1981; Goodwin 1977). Thus the $\mathrm{Sr}$ contents $(60-180 \mathrm{ppm})$ of the Puutturi amphibolites are very similar to those in Archean calc-alkaline metabasalts.

The behaviour of $\mathrm{Cr}, \mathrm{Ni}, \mathrm{Ti}$ and $\mathrm{V}$ in the Puutturi amphibolites could be attributed to by fractionation of mafic phases in general and early commencement of fractionation of magnetite. Partly crossing REE patterns, an increase in $\mathrm{Sr}$ with increasing $\mathrm{Zr}$ and marked variability in the contents of $\mathrm{K}$ indicate that processes other than fractional crystallization must also be considered. These include partial melting, variable enrichments of the mantle by fluids with high, but diverse, contents of LREE, $\mathrm{K}$ and $\mathrm{Sr}$ (e.g. IRS fluids of Gill 1981), assimilation of pre-existing crust or volcanic-sedimentary pile, mixing during possible reworking (tuffites), and alterations at various stages. For example the sample with nearly $5 \% \mathrm{~K}_{2} \mathrm{O}$ is not high in $\mathrm{P}$ and sedimentary mixing or alteration are probable reasons for high $\mathrm{K}$ in this case.

\section{Summary}

Generalized interpretations of aerogeophysical data suggest that the eastern margin of the Proterozoic Kiiminki schist belt covers a smaller area than that proposed earlier.

During systematic field studies for prospecting purposes numerous places were found where the underlying Archean basement and the lowermost parts of the schist belt are exposed at culminations.

Some differences are revealed when basic rocks from both sides of the discordance are compared. The Archean metavolcanics from Käkiperä and Puutturi are often of pyroclastic origin whereas the metabasalts of the Proterozoic schist belt are more often of lava origin. Particularly the (upper) main volcanic unit of the belt contains appreciable pillow basalts.

The basic groups studied also display numerous individual geochemical features.

The Proterozoic metabasalts of the Kiiminki schist belt are tholeiitic. The metabasalts of the main volcanic period, which are often pillowed, bear a particularly marked resemblance to present-day MORB in their low potassium contents, LREE depletion and $(\mathrm{Ti}: \mathrm{Cr}) / \mathrm{Ni}$ ratios. Fractional crystallization can account partly, but not totally, for the compositional variations observed. The earlier volcanic unit (represented by data from Vepsä) is often more »evolved» than the rocks of the main period as is indicated by higher $\mathrm{Zr}$, Ti and $\mathrm{V}$, and lower $\mathrm{Cr}$ and $\mathrm{Ni}$ in the former. However, because the lower unit is relatively high in $\mathrm{K}$ and $\mathrm{Sr}$ it is not wholly comagmatic with the metabasalts of the main period. Further, the high potassium contents in the tuffites at Vepsä (closely associated with nontuffitic rocks) are caused by mixing with pelites. Being low in $\mathrm{V}$ and high in $\mathrm{Zr}$ a few highly evolved rocks of Vepsä indicate late fractionation of magnetite.

The Proterozoic metadiabases of the Puutturi and Käkiperä areas are associated with rifting of the Archean craton. They are also tholeiitic but their $\mathrm{Cr}$ contents (even at low $\mathrm{Zr}$ ) are relatively low. They are medium-K rather than low-K rocks and display slightly LREE-enriched convex-up REE patterns. They are clearly not consanguinuous with the metabasalts of the Kiiminki schist belt (which apparently post-date them).

Of the groups regarded as Archean, the metagabbros of Kalliomaa are high in $\mathrm{Cr}$. This is probably a feature of magma that is not to be attributed to accumulation of mafic silicates. They range from low-K or nearly low-K types (with LREE depletion) to high-K types (with 
slight LREE enrichment). The latter also display Eu minima. The changes in composition can hardly be attributed to fractional crystallization; mixing of magmas or early alteration are more likely.

The Archean amphibolites of Käkiperä are tholeiitic rocks falling mostly at the low-K/medium-K boundary. Their $\mathrm{Cr}$ contents decrease steeply with increasing $\mathrm{Zr}$ but are still higher (at low $\mathrm{Zr}$ ) than those in the Proterozoic metadiabases. The amphibolites display both LREE-depleted and LREE-enriched patterns and they are not related to each other through fractional crystallization.

The Archean amphibolites of Puutturi are medium-K/high-K and high-Cr\&low-Sr rocks with

\section{References}

Allègre, C. J. \& Hart, S. R. (eds), 1978. Trace Elements in Igneous Petrology. A Volume in Memory of Paul W. Gast. Developments in Petrology 5. Elsevier, Amsterdam. 272 p. (Reprinted from Earth Planet. Sci. Lett. V. 38, No 1.)

Arhe, M., 1983 a. Geologinen kartoitus Kiimingin liuskealueella karttalehtien 342402,05 ja 08 alueella. Unpubl. rep. OU 11/83. Rautaruukki Oy Malminetsintä, Oulu.

—, 1983 b. Geologinen kartoitus Kattilasalmien alueella Ylikiimingin Alavuotossa. Unpubl. rep. OU 18/83. Rautaruukki Oy Malminetsintä, Oulu.

Basaltic Volcanism Study Project, 1981. Basaltic Volcanism on the Terrestrial Planets. Pergamon Press, Inc., New York. 1286 p.

Beccaluva, L.; Ohnenstetter, D. \& Ohnenstetter, M., 1979. Geochemical discrimination between ocean-floor and island-arc tholeiites - application to some ophiolites. Can. J. Earth Sci. 16, 1874-1882.

Condie, K. C., 1976. Trace-element geochemistry of Archean greenstone belts. Earth-Sci. Rev. 12, 393-417.

-, 1981. Archean Greenstone Belts. Developments in Precambrian Geology 3. Elsevier, Amsterdam. 434 p.

Cox, K. G.; Bell, J. D. \& Pankhurst, R. J., 1979. The Interpretation of Igneous Rocks. George Allen \& Unwin Ltd, London. 450 p.

Enkovaara, A.; Härme, M. \& Väyrynen, H., 1953. Kivilajikartan selitys. Lehdet C5 Oulu - B5 Tornio. Suomen geologinen yleiskartta 1:400 000 .

Ewart, A., 1982. The mineralogy and petrology of Tertiary- calc-alkaline affinities, stressing their similarity with other Archean calc-alkaline metabasalts. Their REE patterns display consistent LREE enrichments. Partly crossing REE patterns and a general increase in $\mathrm{Sr}$ with increasing $\mathrm{Zr}$ indicates that fractional crystallization of mafic minerals and plagioclase cannot relate the rocks to each other; there must be some other reason.

Acknowledgements. The REE analyses were financed by Finnish Academy Research Project 24/001 led by Dr. T. Koljonen. The paper is a contribution to IGCP Projects 179 "Stratigraphical methods as applied to the Proterozoic record» and $217 »$ Proterozoic geochemistry». We thank Eero Hanski for the useful suggestions he made for the manuscript. The English was corrected by Mrs. Gillian Häkli.

Recent orogenic volcanic rocks: with special reference to the andesitic-basaltic compositional range. Pp. 25-95 in R. S. Thorpe (ed.) Andesites. Orogenic Andesites and Related Rocks. John Wiley \& Sons, Chichester. 724 p. Gill, J. B., 1981. Orogenic Andesites and Plate Tectonics. Minerals and Rocks 16. Springer-Verlag, Berlin. 390 p.

Goodwin, A. M., 1977. Archean volcanism in Superior Province, Canadian Shield. Pp. 206-241 in W. R. A. Baragar, L. C. Coleman and J. M. Hall (eds) Volcanic Regimes in Canada. Geol. Ass. Canada Spec. Paper 16.

Hanski, E. J., 1983. Alkuaineiden jakautuminen mineraalien ja silikaattisulan kesken: Jakaantumiskertoimet. Arkeeisten alueiden malmiprojekti. Raportti 15. Oulun yliopisto.

Hanson, G. N., 1980. Rare earth elements in petrogenetic studies of igneous rocks. Ann. Rev. Earth Planet. Sci. 8, 371-406.

Hawkesworth, C. J. \& Norry, M. J. (eds), 1983. Continental Basalts and Mantle Xenoliths. Shiva Publishing Limited, Cheshire. 272 p.

Honkamo, M., 1980. Stratigraphy of the Northern-Pohjanmaa schist area, 49-54. In: Jatulian geology in the eastern part of the Baltic Shield. Proceedings of a Finnish-Soviet Symposium held in Finland 21st-26th August 1979, ed. by A. Silvennoinen. The Committee for Scientific and Technical Co-operation between Finland and Soviet Union. Rovaniemi 1980. 251 p.

,- 1985 . On the Proterozoic metasedimentary rocks of the Northern Pohjanmaa schist area, Finland. Geol. Surv. Finland, Bull. 331, 117-129.

Huhma, H., 1984. Nd-isotopic composition and age of 
Proterozoic basalts from northern Finland. Terra cognita 4, 192.

Irvine, T. N. \& Baragar, W. R. A., 1971. A guide to the chemical classification of the common volcanic rocks. Can. J. Earth Sci. 8, 523-548.

Jahn, B-M.; Auvray, B.; Blais, S.; Gapdevila, R.; Cornichet, J.; Vidal, R. \& Hameurt, J., 1980. Trace element geochemistry and petrogenesis of Finnish greenstone belts. J. Petrol. 21, 201-244.

Koritnig, S., 1978. Phosphorus. 15-K. Abundance in common sediments and sedimentary rock types. Pp. 15-K-115-K-6 in K. H. Wedepohl (ed.) Handbook of Geochemistry. Springer-Verlag, Heidelberg.

Laajoki, K., 1975. Rare-earth elements in Precambrian iron formations in Väyrylänkylä, South Puolanka area, Finland. Bull. Geol. Soc. Finland 47, 83-107.

Masuda, A.; Nakamura, N. \& Tanaka, T., 1973. Fine structures of mutually normalized rare-earth patterns of chondrites. Geochim. Cosmochim. Acta 37, 239-248.

Mäkinen, E., 1916. Översikt av de prekambriska bildningarna i Mellersta Österbotten i Finland. Bull. Comm. Géol. Finlande 47.

Pearce, J. A., 1982. Trace element characteristics of lavas from destructive plate margins. Pp. 525-548 in R. S. Thorpe (ed.) Andesites. Orogenic Andesites and Related Rocks. John Wiley \& Sons, Chichester. 724 p.

,- 1983 . Role of sub-continental lithosphere in magma genesis at active continental margins. Pp. 230-249 in C.
J. Hawkesworth and M. J. Norry (eds) Continental Basalts and Mantle Xenoliths. Shiva Publishing Limited, Cheshire. 272 p.

Pearce, J. A. \& Cann, J. R., 1973. Tectonic setting of basic volcanic rocks determined using trace element analyses. Earth Planet. Sci. Lett. 19, 290-300.

Pearce, J. A. \& Norry, M. J., 1979. Petrogenetic implications of $\mathrm{Ti}, \mathrm{Zr}, \mathrm{Y}$, and $\mathrm{Nb}$ variations in volcanic rocks. Contrib. Mineral. Petrol. 69, 33-47.

Pekkarinen, L. J., 1979. The Karelian formations and their depositional basement in the Kiihtelysvaara-Värtsilä area, East Finland. Geol. Surv. Finland, Bull. 301.

Perttunen, V., 1983. Peräpohjan eteläosan geologia. Unpubl. Lic. Thesis. Department of Geology, University of Helsinki.

Rosenberg, R. J., 1977. Instrumental neutron activation analysis as a routine method for rock analysis. Technical Research Centre of Finland. Electrical and nuclear technology. Publ. 19.

Shervais, J. W., 1982. Ti-V plots and the petrogenesis of modern and ophiolitic lavas. Earth Planet. Sci. Lett. 59, 101-118.

Simonen, A., 1980 a. Prequaternary rocks of Finland $1: 1000$ 000. Geological Survey of Finland.

-, 1980 b. The Precambrian in Finland. Geol. Surv. Finland, Bull. 304.

Wilkman, W. W., 1931. Kivilajikartan selitys. Lehti C4 Kajaani. Suomen geologinen yleiskartta 1:400 000 . 
Appendix I. General petrography of the samples analysed for REE.

\begin{tabular}{|c|c|c|c|c|c|}
\hline $\begin{array}{l}\text { LOCALITY/ } \\
\text { sample }\end{array}$ & $\begin{array}{l}\text { PLAGIO- } \\
\text { CLASE }\end{array}$ & QUARTZ & $\begin{array}{l}\text { AMPHI- } \\
\text { BOLE }\end{array}$ & BIOTITE & R E M A R K S \\
\hline
\end{tabular}

\section{PYYRÄSELKÄ}

7381-6031 olig-andes, $x \quad$ a $\quad$ act, $x$ $(70-80 \%)$

From a pillow $20 \mathrm{~cm}$ in $ø$. Relics after varioles (see 6032) are rare.

\begin{tabular}{|c|c|c|c|c|}
\hline-6032 & olig-andes, $x$ & & $\begin{array}{l}\text { act, } x \\
(70 \%)\end{array}$ & $\begin{array}{l}\text { From a pillow } 80 \mathrm{~cm} \text { in } ø \text {. Relics after } \\
\text { varioles (presently radiating clusters of } \\
\text { amphibole) are abundant. }\end{array}$ \\
\hline-6033 & olig-andes, $\mathrm{x}$ & $\mathrm{a}$ & act, $x(70 \%)$ & From a pillow $70 \mathrm{~cm}$ in $\varnothing$. \\
\hline-6034 & olig-andes, $x$ & a & $\begin{array}{l}\text { act, } x \\
(70-80 \%)\end{array}$ & $\begin{array}{l}\text { From a pillow } 10 \mathrm{~cm} \text { in } \varnothing \text { with material } \\
\text { less than } 5 \% \text { from matrix. Relics after } \\
\text { phenocrystic and possible skeletal } \\
\text { pyroxene, and amygdules occur. }\end{array}$ \\
\hline
\end{tabular}

\begin{tabular}{|c|c|c|c|c|c|}
\hline-6035 & $\mathrm{x}$ & & act, $x$ & a & $\begin{array}{l}\text { Consists of small chips from pillow matrix } \\
\text { with } 20-30 \% \text { material from pillows. } \\
\text { No thin section, mineral composition } \\
\text { approximated from rock powder. }\end{array}$ \\
\hline \multicolumn{6}{|l|}{ KIVENSELKÄ } \\
\hline 7381-6036 & olig-andes, $\mathrm{x}$ & $\mathrm{x}$ & $\begin{array}{l}\text { act/hbl, x } \\
(60 \%)\end{array}$ & & $\begin{array}{l}\text { From a slightly jointed massive lava. } \\
\text { Pseudomorphs after pyroxene phenocrysts } \\
\text { amount to } 30-40 \%, \varnothing 1 \mathrm{~mm} \text {. }\end{array}$ \\
\hline-6037 & andes, $\mathrm{x}$ & $\mathrm{x}$ & $\begin{array}{l}\text { act, } x \\
(70 \%)\end{array}$ & & $\begin{array}{l}\text { From a strongly elongated pillow. } \\
\text { Amygdules rich in plagioclase and quartz } \\
\text { are obvious. }\end{array}$ \\
\hline-6038 & andes, $\mathrm{x}$ & $\mathrm{a}$ & $\begin{array}{l}\text { act, } x \\
(70 \%)\end{array}$ & $\mathrm{a}$ & $\begin{array}{l}\text { From an elongated pillow. Relics after } \\
\text { pyroxene do occur. Amphibole grains in } \\
\text { elongated patches, c-axis at high angle } \\
\text { across the long dimension of patches; } \\
\text { probable relics of dentritic pyroxene. }\end{array}$ \\
\hline
\end{tabular}

HAAPAMAA

7381-6040 andes, $x \quad$ act, $x$

$(70 \%)$

From a possible pillow in a jointed lava. Nematoblastic, no primary microscopic features remain.

\begin{tabular}{|c|c|c|c|c|c|}
\hline-6041 & andes, $\mathrm{x}$ & & $\begin{array}{l}\text { act, } x \\
(70 \%)\end{array}$ & & $\begin{array}{l}\text { From a possible pillow. Obvious relics } \\
\text { after phenocrysts of pyroxene occur } \\
\text { (ø to } 0.5 \mathrm{~mm} \text { ). }\end{array}$ \\
\hline-6042 & andes, $\mathrm{x}$ & $\mathrm{a}$ & $\begin{array}{l}\text { act, } x \\
(70 \%)\end{array}$ & a & $\begin{array}{l}\text { From a jointed lava. Relics after } \\
\text { phenocrystic ( } \varnothing \text { to } 1 \mathrm{~mm} \text {, ca. } 50 \mathrm{vol} . \%) \\
\text { and some poikilitic pyroxenes occur. }\end{array}$ \\
\hline
\end{tabular}

\begin{tabular}{|c|c|c|c|c|}
\hline $\begin{array}{l}\text { PUUTTURI } \\
7281-2001\end{array}$ & andes, $\mathrm{x}$ & $\begin{array}{l}x \\
(\sim 5 \%)\end{array}$ & $\begin{array}{l}\text { hbl, } x \\
(60-70 \%)\end{array}$ & $\begin{array}{l}x \\
(5 \%)\end{array}$ \\
\hline-2018 & andes-olig, $\mathrm{x}$ & $\begin{array}{l}x \\
(5-20 \%)\end{array}$ & $\begin{array}{l}\mathrm{hbl} / \mathrm{act}, \mathrm{x} \\
(40-60 \%)\end{array}$ & $\begin{array}{l}x \\
(5-20 \%)\end{array}$ \\
\hline
\end{tabular}

A weakly to non-oriented amphibolite. Nematoblastic, but with some affinities to metagabbro. Two thin sections.

\section{Slight compositional layering occurs.}

Possibly volcanoclastic in origin. Mediumgrained oriented nematoblastic amphibolite. Two thin sections. 


\begin{tabular}{|c|c|c|c|c|c|}
\hline $7282-4052$ & olig-alb, $x$ & $(<10 \%)$ & $\begin{array}{l}\mathrm{hbl} / \mathrm{act}, \mathrm{x} \\
(60-70 \%)\end{array}$ & $\begin{array}{l}\mathrm{x} \\
(5-20 \%)\end{array}$ & $\begin{array}{l}\text { Stratified tuff or tuffite. A fine-grained wel } \\
\text { oriented nematoblastic amphibolite. } \\
\text { Two thin sections. }\end{array}$ \\
\hline-4055 & olig-andes, $\mathrm{x}$ & $(\sim 5 \%)$ & $\begin{array}{l}\text { hbl, x } \\
(50-60 \%)\end{array}$ & $\begin{array}{l}\mathrm{a} \\
(5 \%)\end{array}$ & $\begin{array}{l}\text { A moderately oriented, fine-grained } \\
\text { homogeneous nematoblastic amphibolite. } \\
\text { Two thin sections. }\end{array}$ \\
\hline $7283-4001$ & andes, $\mathrm{x}$ & $\left.\begin{array}{l}a \\
(\sim 5\end{array} \%\right)$ & $\begin{array}{l}\text { hbl, x } \\
(50-60 \%)\end{array}$ & $\begin{array}{l}x \\
(10 \%)\end{array}$ & $\begin{array}{l}\text { Fine- to medium-grained nematoblastic } \\
\text { amphibolite. }\end{array}$ \\
\hline-4002 & andes, $\mathrm{x}$ & & $\begin{array}{l}\text { hbl, } x \\
(70 \%)\end{array}$ & $\begin{array}{l}x \\
(10 \%)\end{array}$ & $\begin{array}{l}\text { Amphibole occurs as blastopoikilitic } \\
\text { pseudomorphs after pyroxene phenocrysts } \\
\text { (ø to } 3 \mathrm{~mm} \text { ). A metadiabase with affinities } \\
\text { to metagabbro. }\end{array}$ \\
\hline
\end{tabular}

\begin{tabular}{|c|c|c|c|c|c|}
\hline $\begin{array}{l}\text { KÄKIPERÄ } \\
7383-0002\end{array}$ & andes-labr, $\mathrm{x}$ & $(\sim 10 \%)$ & $\begin{array}{l}\text { hbl, x } \\
(40 \%)\end{array}$ & $\mathrm{a}$ & $\begin{array}{l}\text { From a fragment in a possible flow-breccia. } \\
\text { A medium-grained, well oriented } \\
\text { nematoblastic amphibolite. }\end{array}$ \\
\hline-0003 & andes, $\mathrm{x}$ & $(\sim 10 \%)$ & $\begin{array}{l}\text { hbl, } x \\
(40 \%)\end{array}$ & $\mathrm{a}$ & $\begin{array}{l}\text { From a fragmented (flow-breccia?) strata. } \\
\text { An even- and medium-grained oriented } \\
\text { nematoblastic amphibolite. }\end{array}$ \\
\hline-0006 & andes, $\mathrm{x}$ & $\mathrm{x}$ & $\begin{array}{l}\text { hbl, x } \\
(70-80 \%)\end{array}$ & & $\begin{array}{l}\text { A fine-grained, oriented nematoblastic } \\
\text { amphibolite of possible lava origin. }\end{array}$ \\
\hline-0004 & andes, $\mathrm{x}$ & $(\sim 10 \%)$ & $\begin{array}{l}\text { hbl, } x \\
(60 \%)\end{array}$ & & $\begin{array}{l}0.5 \mathrm{~m} \text { from the contact of the metadiabase. } \\
\text { Blastopoikilitic grains of amphibole } \\
\text { (formerly pyroxene) up to } 4 \mathrm{~mm} \text { in } \oslash \text {. }\end{array}$ \\
\hline-0005 & andes, $\mathrm{x}$ & a & $\begin{array}{l}\text { hbl, x } \\
(60-70 \%)\end{array}$ & & $\begin{array}{l}3.5 \mathrm{~m} \text { from the contact of the metadiabase. } \\
\text { Blastopoikilitic grains of amphibole } \\
\text { (formerly pyroxene) up to } 4 \mathrm{~mm} \text { in } \varnothing \text {. }\end{array}$ \\
\hline $\begin{array}{l}\text { KALLIOMAA } \\
7383-0020\end{array}$ & labr, $x$ & $\begin{array}{l}\mathrm{a} \\
(5 \%)\end{array}$ & $\begin{array}{l}\text { act } / \mathrm{hbl}, \mathrm{x} \\
(40-50 \%)\end{array}$ & $\begin{array}{l}x \\
(10-20 \%)\end{array}$ & $\begin{array}{l}\text { The primary texture of a gabbro is well } \\
\text { discernable, the texture is partly almost } \\
\text { blastophitic. Amphibole could be relic of } \\
\text { pyroxene. }\end{array}$ \\
\hline-0022 & labr, $x$ & & $\begin{array}{l}\text { hbl/act, } x \\
(70 \%)\end{array}$ & & $\begin{array}{l}\text { The typical texture of a gabbro is not } \\
\text { obvious. }\end{array}$ \\
\hline-0023 & andes-labr, $x$ & a & $\begin{array}{l}\text { hbl, } x \\
(40-50 \%)\end{array}$ & $\begin{array}{l}\mathrm{a} \\
(<1\end{array}$ & $\begin{array}{l}\text { The fairly well preserved texture of a } \\
\text { gabbro has blastophitic affinities. }\end{array}$ \\
\hline-0024 & andes, $\mathrm{x}$ & $\begin{array}{l}\mathrm{a} \\
(5 \%)\end{array}$ & $\begin{array}{l}\text { hbl/act, } \mathrm{x} \\
(40 \%)\end{array}$ & $\begin{array}{l}\mathrm{a} \\
(5 \%)\end{array}$ & $\begin{array}{l}\text { The texture of a gabbro is well identifiable } \\
\text { and it approaches blastophitic. Plagioclase } \\
\text { has been partly granulated and replaced by } \\
\text { quartz. }\end{array}$ \\
\hline
\end{tabular}

$\mathrm{x}$ : a major phase $(>5$ vol. $\%)$.

a: a minor or accessory phase.

act in the column of amphibole denotes pale green »actinolitic» amphibole.

Samples from Pyyräselkä are from a pillowed flow in a single outcrop. Samples from Puutturi are from drill cores.

Samples 0004 and 0005 from Käkiperä are from a single dyke. 
Appendix II. Derivation of samples 6031-6033 from samples 6037-6038 by $40 \%$ fractional crystallization of $\mathrm{PLAG}_{0.7} \mathrm{CPX}_{0.15} \mathrm{OL}_{0.15}$; comparison of calculated and observed compositions.

\begin{tabular}{lcccrccccc}
\hline & $\mathrm{Zr}$ & $\mathrm{Sr}$ & $\mathrm{Cr}$ & $\mathrm{Ni}$ & $\mathrm{V}$ & $\mathrm{La}$ & $\mathrm{Sm}$ & $\mathrm{Eu}$ & $\mathrm{Yb}$ \\
\hline $\mathrm{C}_{\mathrm{O}}$ & 50 & 115 & 260 & 130 & 260 & 1.01 & 1.61 & 0.63 & 1.73 \\
$\mathrm{C}_{\mathrm{L}}$, calc. & 82 & 87 & 198 & 86 & 283 & 1.59 & 2.56 & 0.93 & 2.6 \\
$\mathrm{C}_{\mathrm{L}}$, obs. & 80 & 80 & 180 & 80 & 290 & 1.65 & 2.4 & 0.87 & 2.5 \\
& & -90 & -190 & -100 & -320 & -2.0 & -2.7 & -0.99 & -2.8 \\
\hline $\mathrm{D}-$ values & & & & & & & & & \\
used & & & & & & & & & \\
$\mathrm{D}_{\text {cpx }}$ & 0.1 & 0.07 & 10 & 2 & 5 & 0.07 & 0.26 & 0.2 & 0.28 \\
$\mathrm{D}_{\text {ol }}$ & 0.01 & 0.001 & 0.2 & 10 & 0.1 & 0.001 & 0.002 & 0.002 & 0.002 \\
$\mathrm{D}_{\text {plag }}$ & 0.01 & 2.2 & 0.01 & 0.01 & 0.1 & 0.2 & 0.07 & 0.3 & 0.03 \\
\hline
\end{tabular}

The calculations are based on the Rayleigh equation $\mathrm{C}_{\mathrm{L}}=\mathrm{C}_{\mathrm{O}} \mathrm{F}^{(\mathrm{D}-1)}$ where

$\mathrm{C}_{\mathrm{L}}$ is the concentration of the element in the residual melt

$\mathrm{C}_{\mathrm{O}}$ is the concentration of the element in the parental melt

$F$ is the proportion of melt left

$\overline{\mathrm{D}}$ is the bulk distribution coefficient $(\overline{\mathrm{D}}=\Sigma \mathrm{XD}$, where $\mathrm{X}$ is the fraction of each mineral in the solid residue and $\mathrm{D}$ the distribution coefficient of each mineral)

$\mathrm{F}=0.6$ was approximated from $\frac{\mathrm{Zr}_{\mathrm{O}}}{\mathrm{Zr}_{\mathrm{L}}}=\frac{50}{80}$ (given that $\overline{\mathrm{D}}_{\mathrm{Zr}}$ approaches zero for a fractionated solid residue composed of PLAG + CPX + OL).

Composition of solid residue ( $70 \%$ PLAG, $15 \%$ CPX, $15 \%$ OL) was initially approximated from $\mathrm{Sr}, \mathrm{Cr}$ and $\mathrm{Ni}$ in samples 6031-6033 and 6037-6038 (given that e.g. $\overline{\mathrm{D}}_{\mathrm{Sr}}$ is just slightly influenced by CPX and OL; the proportion of PLAG in the solid residue can then be approximated from changes in $\mathrm{Sr}$ ).

$\mathrm{C}_{\mathrm{O}}$ for $\mathrm{Zr}$ and $\mathrm{REE}$ from sample 6037, and for $\mathrm{Sr}, \mathrm{Cr}$, Ni and $\mathrm{V}$ as averages from samples 6037-6038.

$\mathrm{C}_{\mathrm{L}}$, obs. is the range in samples 6031-6033.

$\mathrm{D}$ values for $\mathrm{Sr}, \mathrm{Cr}$, Ni and REE from Cox et al. (1979, La extrapolated from the other REE). $\mathrm{D}_{\mathrm{Zr}}$ from Pearce and Norry (1979). $D_{V}$ approximated from data in Hanski (1983), except $D_{V}^{\text {cpx }}$, which is from Shervais (1982) for augite at $\mathrm{f}_{\mathrm{O}_{2}}=10^{-12}$ (a reasonable approximation of oxygen fugacity in MORB, see Basaltic Volcanism Study Project 1981, p. 138). 